Atmos. Chem. Phys., 13, 12271-12298, 2013

www.atmos-chem-phys.net/13/12271/2013/

doi:10.5194/acp-13-12271-2013

(c) Author(s) 2013. CC Attribution 3.0 License.

\title{
Long-term measurements of aerosol and carbon monoxide at the ZOTTO tall tower to characterize polluted and pristine air in the Siberian taiga
}

\author{
X. Chi ${ }^{1}$, J. Winderlich ${ }^{1}$, J.-C. Mayer ${ }^{1}$, A. V. Panov ${ }^{2}$, M. Heimann ${ }^{3}$, W. Birmili ${ }^{4}$, J. Heintzenberg ${ }^{4}$, Y. Cheng ${ }^{1}$, and \\ M. O. Andreae ${ }^{1}$ \\ ${ }^{1}$ Biogeochemistry Department, Max Planck Institute for Chemistry, 55020 Mainz, Germany \\ ${ }^{2}$ V. N. Sukachev Institute of Forest, Krasnoyarsk, 660036, Russia \\ ${ }^{3}$ Max Planck Institute for Biogeochemistry, 07745 Jena, Germany \\ ${ }^{4}$ Leibniz Institute for Tropospheric Research, 04318 Leipzig, Germany
}

Correspondence to: X. Chi (xuguang.chi@mpic.de)

Received: 17 May 2013 - Published in Atmos. Chem. Phys. Discuss.: 9 July 2013

Revised: 22 October 2013 - Accepted: 24 October 2013 - Published: 18 December 2013

\begin{abstract}
Siberia is one of few continental regions in the Northern Hemisphere where the atmosphere may sometimes approach pristine background conditions. We present the time series of aerosol and carbon monoxide (CO) measurements between September 2006 and December 2011 at the Zotino Tall Tower Observatory (ZOTTO) in Central Siberia $\left(61^{\circ} \mathrm{N} ; 89^{\circ} \mathrm{E}\right)$. We investigate the seasonal, weekly and diurnal variations of aerosol properties (including absorption and scattering coefficients and derived parameters, such as equivalent black carbon $\left(\mathrm{BC}_{\mathrm{e}}\right)$, Ångström exponent, single scattering albedo, and backscattering ratio) and the $\mathrm{CO}$ mixing ratios. Criteria were established to distinguish polluted from near-pristine air masses, providing quantitative characteristics for each type. Depending on the season, 23-36\% of the sampling time at ZOTTO was found to be representative of a clean atmosphere. The summer pristine data indicate that primary biogenic and secondary organic aerosol formation are quite strong particle sources in the Siberian taiga. The summer seasons 2007-2008 were dominated by an Aitken mode around $80 \mathrm{~nm}$ size, whereas the summer 2009 with prevailing easterly winds produced particles in the accumulation mode around $200 \mathrm{~nm}$ size. We found these differences to be mainly related to air temperature, through its effect on the production rates of biogenic volatile organic compounds (VOC) precursor gases. In winter, the particle size distribution peaked at $160 \mathrm{~nm}$, and the footprint of clean background air was characteristic for aged particles from anthropogenic sources
\end{abstract}

at great distances from ZOTTO and diluted biofuel burning emissions from domestic heating. The wintertime polluted air originates mainly from large cities south and southwest of the site; these particles have a dominant mode around $100 \mathrm{~nm}$, and the $\Delta \mathrm{BC}_{\mathrm{e}} / \Delta \mathrm{CO}$ ratio of $7-11 \mathrm{ng} \mathrm{m}^{-3} \mathrm{ppb}^{-1}$ suggests dominant contributions from coal and biofuel burning for heating. During summer, anthropogenic emissions are the dominant contributor to the pollution particles at ZOTTO, while only $12 \%$ of the polluted events are classified as biomass-burning-dominated, but then often associated with extremely high CO concentrations and aerosol absorption coefficients. Two biomass-burning case studies revealed different $\triangle \mathrm{BC}_{\mathrm{e}} / \triangle \mathrm{CO}$ ratios from different fire types, with the agricultural fires in April 2008 yielding a very high ratio of $21 \mathrm{ng} \mathrm{m}^{-3} \mathrm{ppb}^{-1}$. Overall, we find that anthropogenic sources dominate the aerosol population at ZOTTO most of the time, even during nominally clean episodes in winter, and that near-pristine conditions are encountered only in the growing season and then only episodically.

\section{Introduction}

Siberia, a vast region in Central Eurasia, has been gaining growing attention from atmospheric aerosol researchers in the last few decades. The atmospheric aerosol over Siberia is of particular interest for several reasons: firstly, biogenic 
emissions of volatile organic compounds (VOC) from the vast boreal taiga forest are thought to lead to the formation of secondary organic aerosol (SOA) (Tunved et al., 2006). Secondly, Siberia has been documented as a source region of biomass-burning aerosol particles that are distributed around the globe in the free troposphere (Conard and Ivanova, 1997; Müller et al., 2005; Warneke et al., 2009). Thirdly, Siberia is one of few possible background regions in the Northern Hemisphere, where conditions approaching pristine might sometimes prevail. In the following, we will use the term "pristine" when referring to periods with relatively minor anthropogenic influence. We are well aware that truly pristine conditions do not exist anymore, due to the pervasive effect of long-range transport of anthropogenic emissions (Andreae, 2007). However, atmospheric observations in remote areas are very important for providing a reference for evaluating anthropogenic impacts in this and other regions.

Atmospheric aerosols affect the climate system both directly and indirectly. The simplest description of the direct aerosol climate effect is that absorption by aerosol tends to heat the atmosphere, whereas scattering into the upward hemisphere tends to cool it; thus, the two most important optical properties of aerosol as far as climatic change is concerned are light absorption and scattering. Since the atmospheric aerosol is highly inhomogeneous and variable, aerosol scattering and absorption show a large spatial and temporal variability. Therefore, it is necessary to measure these properties at the regional scale with at least daily temporal resolution for a better understanding of aerosol's direct climate effects and an improved ability to model climate. Despite a large number of studies, there remain significant gaps in our current observational coverage, particularly in background regions such as Siberia.

Aerosol light absorption and scattering can be characterized by the absorption coefficient, $\sigma_{\mathrm{ap}}$, and the scattering coefficient, $\sigma_{\mathrm{sp}}$, respectively, which describe the decrease of light intensity per distance and are therefore given in units of inverse meter (or inverse mega meter; $1 \mathrm{Mm}^{-1}=10^{-6} \mathrm{~m}^{-1}$ ). The influence of aerosol on the atmosphere and surface depends importantly on the relative balance between absorption and scattering, often expressed as the single scattering albedo, $\omega_{0}$, which is the ratio of aerosol scattering over extinction (the sum of absorption and scattering). Studies show that the single scattering albedo determines the sign (cooling/heating) of the aerosol radiative forcing (Hansen et al., 1997). It is generally thought that the optical properties of aerosol are related to a rather limited set of physical and chemical features. For example, the single scattering albedo is found to be a function of the refractive index (mainly its imaginary part, $k$ ) and particle size (Dubovik et al., 2002). Under present-day conditions, the main absorbing component of aerosol in the visible wavelength range is black carbon (BC), also referred to as "elemental carbon" or "soot carbon" (for a detailed discussion, see Andreae and Gelencsér, 2006). BC is essentially a primary pollutant, emitted directly into the atmosphere predominantly during incomplete combustion of various carbonaceous fuels. On a global scale, the most important sources of BC are fossil fuel combustion and biomass burning (Gelencsér, 2004; Andreae and Rosenfeld, 2008; Bond et al., 2013). Another important contribution to absorption, particularly at shorter wavelengths, comes from light-absorbing organic carbon, or "brown carbon" $(\mathrm{BrC})$ (Kirchstetter et al., 2004; Andreae and Gelencsér, 2006; Chung et al., 2012), which can originate from biomass burning or from the atmospheric ageing of secondary organic aerosol (Zhang et al., 2011b; Lack et al., 2012; Nguyen et al., 2012). In remote vegetated regions, biogenic organic carbon makes a significant contribution to aerosol light absorption (Guyon et al., 2003, 2004). Mineral dust (mainly in the coarse size fraction) can account for a considerable fraction of light absorption, especially in regions influenced by desert dust (Chung et al., 2012). According to Mie theory, aerosol scattering is light-wavelength-dependent, and this wavelength dependence of the scattering is a strong function of both the composition and the size of the aerosol particles. Particles with a diameter that is comparable to the wavelength of solar radiation $(0.2-2 \mu \mathrm{m})$ are the most effective light scatterers (Waggoner et al., 1981), which makes organic carbon and some inorganic species (e.g., sulfate, nitrate, ammonium) in the submicrometer size range typically the most effective chemical components of aerosol scattering.

The indirect effects of aerosols result from their CCN (cloud condensation nuclei) and IN (ice nuclei) activity, through which aerosols change the optical properties, the hydrometeor type and size, and the life cycle of clouds. At a given water vapor supersaturation, the effectiveness of a particle as a CCN depends on its size and the fraction of soluble matter it contains. The latter is now frequently represented by the hygroscopicity factor, $\kappa$, which by definition is a function of the supersaturation and dry particle diameter (Petters and Kreidenweis, 2007), and can be determined experimentally from hygroscopicity tandem differential mobility analyzer (HTDMA) or CCN measurement data. The hygroscopicity factor, $\kappa$, typically falls in the range of $0.1-0.9$ for ambient aerosols (Petters and Kreidenweis, 2007; Andreae and Rosenfeld, 2008). At these $\kappa$ values, the maximum of the CCN size distribution typically is in the range of about 70$200 \mathrm{~nm}$ at the supersaturations commonly found in clouds (up to about $0.6 \%$ ). In most cases, the variability in particle size exerts the strongest influence on the variability of particles to be able to act as CCN (Dusek et al., 2006).

Atmospheric aerosol particles have diameters ranging from a few nanometers to 100 micrometers. Over this vast size range, the properties of aerosols and their associated effects on visibility, climate, health, and welfare vary substantially. Because size plays such an important role (Dusek et al., 2006), in order to better characterize aerosols, it is important to know the size distribution of important particle properties (e.g., number, volume or mass). Based on the analysis of different particle size spectra, Whitby 
(1978) suggested that atmospheric particles usually occur in specific size groupings (modes) that differ in their origins and properties. Submicrometer particles are frequently treated in terms of three modes based on their particle diameter $\left(D_{\mathrm{p}}\right)$, "the nucleation mode" $\left(D_{\mathrm{p}}<10 \mathrm{~nm}\right)$, the "Aitken mode" $\left(10 \mathrm{~nm}<D_{\mathrm{p}}<100 \mathrm{~nm}\right)$, and the "accumulation mode" $\left(100 \mathrm{~nm}<D_{\mathrm{p}}<1000 \mathrm{~nm}\right)$. The nucleation mode contains newly formed particles arising through homogeneous nucleation, and can often only be observed in the immediate vicinity of their sources or during active nucleation events. Aitken mode particles may result from primary emissions from high temperature combustion, as well as growth of nucleation mode particles, or nucleation from higher concentration precursors. As to the accumulation mode particles, some of them are primary (e.g., from combustion) while others are secondary and have grown from smaller particles mainly by condensation and cloud processing. The accumulation mode particles have long lifetimes and therefore can travel long distances. Because of their high CCN efficiency and large optical cross section, they are also the most important particle class in the context of aerosol climate forcing.

Carbon monoxide (CO) is an important atmospheric trace gas and plays a critical role in the atmospheric chemical system. It is the dominant sink of the hydroxyl radical $(\mathrm{OH})$, thus affecting the lifetimes of many trace gas species (such as methane, $\mathrm{CH}_{4}$ ) that are removed following reaction with $\mathrm{OH}$. Carbon monoxide also affects regional air quality. In areas with sufficient $\mathrm{NO}_{\mathrm{x}}, \mathrm{HO}_{2}$ produced from oxidization of $\mathrm{CO}$ can initiate photochemical reactions that result in the net formation of $\mathrm{O}_{3}$. In IPCC 2001 (Houghton et al., 2001), $\mathrm{CO}$ was identified as an important indirect greenhouse gas, although it itself absorbs only little infrared radiation from the Earth (Daniel and Solomon, 1998). It is generally agreed that the main sources of $\mathrm{CO}$ are primary emissions from anthropogenic pollution (combustion of fossil fuel and biofuels, and industrial emission) and open biomass burning, and secondary $\mathrm{CO}$ from photochemical oxidation of $\mathrm{CH}_{4}$ and nonmethane hydrocarbons (Novelli et al., 1998; Duncan et al., 2007). The major sink (>95\%) for CO is its reaction with $\mathrm{OH}$ (Duncan and Logan, 2008). Although at the global and annual scale, the main $\mathrm{CO}$ sources are of comparable magnitude, the uneven distribution, especially of the combustion sources and CO's relatively short lifetime (around one to two months on average), cause large spatial and temporal variability of atmospheric CO. In the northern mid- and high latitudes, anthropogenic emissions dominate $\mathrm{CO}$ sources in winter, while oxidation of volatile organic compounds (VOCs) is the largest source of $\mathrm{CO}$ in summer. Modeling and observational studies suggest that strong natural and humaninduced boreal forest fires, occurring mainly in Siberia, are a main cause of the increased $\mathrm{CO}$ burdens in the northern hemispheric summer during specific years (Kasischke et al., 2005; Yurganov et al., 2005; Vasileva et al., 2011). During recent decades, measurements of $\mathrm{CO}$ in the troposphere have been made at various locations around the world, but very few exist from the vast regions of northern Eurasia. Sustained, long-term measurements of $\mathrm{CO}$ in this region could be helpful to improve our understanding of spatial and temporal variations of global $\mathrm{CO}$, and are of importance as input information for source inversion models (Kopacz et al., 2010; Fisher et al., 2010) and for validation of other models, e.g., chemical transport models (Zhang et al., 2008).

In 2006 the $300 \mathrm{~m}$ tower of the Zotino Tall Tower Observatory (ZOTTO) was established in Central Siberia. The background character and the geographical location of this station are appropriate conditions for studying atmospheric transport and coincident chemical transformation of polluted air at a wide range of spatial and temporal scales, particularly for assessing the potential influence of emissions from various natural and anthropogenic sources on surface air composition over the large territory of Siberia. The remote location of ZOTTO in the middle of the Siberian taiga forest also makes it highly suitable for investigating the exchange of trace gases with this ecosystem and the production of aerosol by the boreal forest. Continuous measurements of comprehensive sets of atmospheric constituents in the gas and particle phase together with meteorological parameters have been carried out at ZOTTO since October 2006 (Kozlova et al., 2008; Heintzenberg et al., 2008). With regards to aerosol, a study of the representativeness of the ZOTTO facility and first analyses of the particle size distribution data can be found in Heintzenberg et al. (2008) and Heintzenberg and Birmili (2010); a statistical analysis of particle size distribution, particle absorption, and $\mathrm{CO}$ data taken from the first four years of operation of the ZOTTO facility (September 2006 to January 2010) is given in Heintzenberg et al. (2011), together with seasonally dependent major air mass pathways and the related particle size distributions.

In this paper, we extend the statistical analysis of aerosol properties to include scattering coefficients and the derived optical parameters, Ångström exponent $(\stackrel{a}{a})$, single scattering albedo $\left(\omega_{0}\right)$, and backscattering ratio $(b)$. The additional year of data (up to December 2011) now available enables us to fill the CO data gap for June that existed in the seasonal variation analysis shown in the previous paper. In addition to seasonal variations, we investigate here the weekly and diurnal variations of the measured and calculated aerosol parameters and CO. Furthermore, we have developed criteria to distinguish polluted and near-pristine airmasses and characterize them separately. The paper is organized as follows: section 2 describes the sampling and measurement techniques applied at the ZOTTO site and the methodology used for data analysis and interpretation in this study. In Sect. 3 we discuss the seasonal and synoptic variability of aerosol properties and $\mathrm{CO}$ at ZOTTO; using the residence time analysis and trajectory statistics, we connect this variability with climatically important anthropogenic sources and wildfire emissions affecting the measurement site; in addition we present the representative characteristics of polluted and near-pristine air. 
The results of the study are summarized in the conclusions, in Sect. 4.

\section{Measurements and methods}

\subsection{Sampling}

The Zotino Tall Tower Observatory (ZOTTO) is located near the Yenisei River at the eastern edge of the West Siberia Lowland in the boreal zone $\left(60.80^{\circ} \mathrm{N}\right.$ and $89.35^{\circ} \mathrm{E}, 114 \mathrm{~m}$ a.s.l.), about $600 \mathrm{~km}$ north of the closest large city, Krasnoyarsk (950 000 inhabitants) (Lavric et al., 2011). The nearest village (Zotino) is about $20 \mathrm{~km}$ to the east of the site. The site lies in a vast region of boreal coniferous taiga forest and bogs. The area around the tower is characterized by a low influence from anthropogenic pollution, which makes it an excellent location for a mid-continental background station (Heintzenberg et al., 2008; Winderlich et al., 2010). The climate is dominated by a large seasonal temperature cycle reaching from minima below $-55^{\circ} \mathrm{C}$ in winter to maxima above $30^{\circ} \mathrm{C}$ in summer. The heart of the station is a $304 \mathrm{~m}$ high tower, which was designed for long-term atmospheric observations, and the air masses sampled at the tower are representative of a very large area (Gloor et al., 2001).

Ambient air is sampled through two independent inlet pipes, one reaching to the top of the tower at $300 \mathrm{~m}$ above ground, and the other one to a height of $50 \mathrm{~m}$. Both inlets are conducted into an underground laboratory container, where the incoming sample air is analyzed by different instruments. The inlet pipes are made of stainless steel with an internal diameter of about $2.8 \mathrm{~cm}$, and were designed for a nominally laminar sampling flow of $40 \mathrm{~L} \mathrm{~min}^{-1}$. Pre-installation calibration showed that particles with diameters $\left(D_{\mathrm{p}}\right)>50 \mathrm{~nm}$ are transmitted almost without loss through the pipe, and that $10 \mathrm{~nm}$ particles are still transmitted at a reproducible efficiency of $20 \%$ (Birmili et al., 2007). The upper cut-off diameter for the inlet system was estimated to be $2-3 \mu \mathrm{m}$. A computer-controlled valve system switches the air sampling between the two height levels every six minutes while maintaining the nominal $40 \mathrm{~L} \mathrm{~min}^{-1}$ flow in both inlets. The airflow through this system is divided into several separate streams, and directed to the individual instruments described in the following section.

\subsection{Instrumentation}

\subsubsection{Particulate scattering measurements}

For measuring particulate scattering, we use a threewavelength integrating nephelometer (TSI 3563, St. Paul, MN, USA). With a backscatter shutter, this nephelometer is designed to measure aerosol scattering $\left(\sigma_{\mathrm{sp}}\right)$ and hemispheric backscattering coefficients $\left(\sigma_{\mathrm{bsp}},\right)$ at three wavelengths ( 450 , 550 , and $700 \mathrm{~nm}$; also referred to as "blue", "green", and "red"). The backscattering ratio (b) at each wavelength can be calculated by

$\mathrm{b}=\frac{\sigma_{\mathrm{bsp}}}{\sigma_{\mathrm{sp}}}$.

The instrument is described in detail by Anderson et al. (1996b) and Anderson and Ogren (1998). The nephelometer is operated with a flow rate of $10 \mathrm{~L} \mathrm{~min}^{-1}$. Calibration is carried out by using $\mathrm{CO}_{2}$ as the high span gas and filtered air as the low span gas. The zero signal is measured once every two hours using filtered ambient air. Noise level and detection limits for the TSI 3563 have been investigated by Anderson et al. (1996b). At low particle concentrations and/or short sampling times, random noise tends to dominate the nephelometer uncertainties. For the $300 \mathrm{~s}$ averages applied here, the detection limits, defined as a signal to noise ratio of 2 , for scattering coefficients are $0.45,0.17$, and $0.26 \mathrm{Mm}^{-1}$ for 450,550 , and $700 \mathrm{~nm}$, respectively. This assessment includes measurement noise and noise during the zeroing procedure with filtered air (Anderson et al., 1996b). For particle scattering coefficients above about $1 \mathrm{Mm}^{-1}$ and averaging times longer than about $60 \mathrm{~s}$, the dominant source of uncertainty is the systematic uncertainty, including the calibration uncertainty and the uncertainty from wavelength and angular nonidealities. Compared with uncertainties associated with nonidealities, the calibration uncertainties are very small (contributing about $1 \%$ of uncertainty in particle scattering measurements, Anderson et al., 1996b), and are not size dependent. Within the non-idealities uncertainties, the wavelength non-idealities have been shown to be of secondary importance in previous studies and are often neglected. For the TSI 3563, the dominant angular non-ideality is the forward scattering truncation from $0^{\circ}$ to approximately $7^{\circ}$; the magnitude of this error increases systematically with particle size. In order to correct for this issue, a truncation correction is applied to the measured values, which accounts both for the lack of illumination at extreme angles (near $0^{\circ}$ and $180^{\circ}$ ) and for the slightly non-sinusoidal illumination function of the light source. The truncation correction is defined as

$C=\frac{\sigma_{\mathrm{sp}, \text { true }}}{\sigma_{\mathrm{sp}, \text { neph }}}$,

where $\sigma_{\mathrm{sp} \text {, true }}$ is the true scattering by particles and $\sigma_{\mathrm{sp} \text {, neph }}$ is the scattering measured by the nephelometer.

The truncation correction factor $\mathrm{C}$ for the TSI 3563 instrument can be estimated from the Ångström exponent $(\stackrel{\circ}{a})$ measured internally as the wavelength dependence of the scattering coefficient

$\therefore\left(\frac{\lambda_{1}}{\lambda_{2}}\right)=-\frac{\log \left(\sigma_{\mathrm{sp}, \text { neph }}\left(\lambda_{1}\right) / \sigma_{\mathrm{sp}, \text { neph }}\left(\lambda_{2}\right)\right)}{\log \left(\lambda_{1} / \lambda_{2}\right)}$.

Anderson and Ogren (1998) have shown that both $a$ and $C$ are size-dependent and that these two size-dependent parameters are correlated well over certain size ranges. They presented a set of three linear, empirical relationships, each averaged over the range of optical properties investigated, to 
estimate the truncation correction at each of the TSI nephelometer's wavelengths $(450,550$, and $700 \mathrm{~nm})$. Since submicrometer particles predominate in the particle number size distribution at our remote continental site (Koutsenogii and Jaenicke, 1994), the sub-micron (as opposed to super-micron correction or an average of the two) corrections presented in Table 4 of Anderson and Ogren (1998) are used for the truncation corrections to the nephelometer in this study. Bond et al. (2009) suggest that the Anderson and Ogren (1998) correction is accurate to within $2 \%$ for a wide range of atmospheric particles, but that the error could be as high as $5 \%$ for highly absorbing particles.

\subsubsection{Particulate light absorption measurements}

A single-wavelength Particle/Soot Absorption Photometer (PSAP, Radiance Research, Seattle, USA) was used in this study for measuring the light absorption by particles. The method is based on the integrating plate technique, in which the change in optical transmission through a filter caused by particle deposition on the filter is related to the light absorption coefficient of the deposited particles. The raw absorption coefficient of the PSAP is given by

$\sigma_{0}=\frac{A}{V} \ln \left(\frac{\operatorname{Tr}_{t-\Delta t}}{\operatorname{Tr}_{t}}\right)$,

where $A$ is the area of the sample spot, $V$ is the volume of air drawn through the spot area during a given time period $\Delta t$, $\operatorname{Tr}_{t-\Delta t}$ and $\operatorname{Tr}_{t}$ are the filter transmission before and after the time period, respectively, and $\sigma_{0}$ is the raw or uncorrected absorption coefficient from the PSAP. However, it is known that this equation does not directly give the real absorption coefficient by particles, because of the inherent errors caused by the multiple scattering effects within the filter matrix and the scattering by the collected particles (Bond et al., 1999; Virkkula et al., 2005).

Several empirical correction methods have been suggested and modified for handling these artifacts (Bond et al., 1999; Weingartner et al., 2003; Virkkula et al., 2005). In this study we correct our data for the scattering artifact as well as for calibration errors after Virkkula et al. (2005). The absorption coefficient for particles is calculated from

$\sigma_{\mathrm{ap}}(\mathrm{PSAP})=\left(k_{0}+k_{1}\left(h_{0}+h_{1} \omega_{0}\right) \ln (\mathrm{Tr})\right) \sigma_{0}-s \sigma_{\mathrm{sp}}$,

where $k_{0}, k_{1}, h_{0}, h_{1}$, and $s$ are the constants listed in Table 3 of Virkkula et al. (2005) for a single wavelength PSAP $(\lambda=574 \mathrm{~nm}), \operatorname{Tr}$ is the transmission of the light through the filter, $\sigma_{\mathrm{sp}}$ represents the scattering coefficient $(\lambda=574 \mathrm{~nm})$, $\omega_{0}$ is the single-scattering albedo, which is calculated using the iterative procedure (Eqs. 7-9 and Table 3) described in Virkkula et al. (2005). It has been estimated that this type of empirical correction provides an overall accuracy for PSAP measurements of ca. 20-30\% (Bond et al., 1999). These estimates of the uncertainty in PSAP absorption are derived from laboratory measurements, typically made using nonabsorbing (e.g., ammonium sulfate) or strongly absorbing (e.g., soot, nigrosin dye) particles, which are all solid when dry (Bond et al., 1999; Virkkula et al., 2005). Some later laboratory and field experiments (Cappa et al., 2008; Lack et al., 2008) suggest that the actual uncertainty in PSAP measurements in the field is likely to be significantly larger than the estimate of $20-30 \%$. The minimum detection limit (MDL) of the PSAP was estimated to be $0.025 \mathrm{Mm}^{-1}$ for our hourlyaverage data, which is determined by two times the standard deviation of $1 \mathrm{~min}$ noise (with $60 \mathrm{~s}$ cycle time), as reported in Virkkula et al. (2005). The interpolation from one time basis to another is as follows:

$\mathrm{MDL}_{t 1}=\mathrm{MDL}_{t 2} \sqrt{\frac{t 2}{t 1}}$,

where $t 1$ and $t 2$ are the two time bases.

At the site, the PSAP was attended to regularly and the filter was changed when the filter transmission reached 0.7 . The aerosol flow through the instrument varied slightly around a value of $0.3 \mathrm{~L} \mathrm{~min}^{-1}$. The exact flow rate (average of at least three measurements) is measured every time the filter is changed, and is used for sampling flow calculations. The measured diameter of the sampling spot on several filters is $5.2 \mathrm{~mm}$, which differs from the $5.0 \mathrm{~mm}$ given in the PSAP specifications. Along with the switching times between the $300 \mathrm{~m}$ and $50 \mathrm{~m}$ height levels, the filter transmission values (Tr) from the PSAP are recorded at the beginning and end of each individual time period (either for $300 \mathrm{~m}$ or $50 \mathrm{~m}$ height levels). Our initial goal was to calculate the absorption coefficient during each of these time periods separately, using the equations mentioned above, and then convert them to $1 \mathrm{~h}$ averages for each height level. However, it was found that the filter transmission (Tr) sometimes increases instead of decreasing for the $300 \mathrm{~m}$ height levels during summer, which leads to a negative absorption coefficient for $300 \mathrm{~m}$. We further found that this phenomenon generally occurs when the relative humidity differences between the two height levels are significant (e.g., larger than $2 \%$ ). This indicates that humidity changes, even at low RH, can affect light transmission through the PSAP filter (Anderson et al., 2003). In order to avoid these problems we first calculated the hourly average absorption coefficient for the sum of both height levels, and then partitioned the data into $50 \mathrm{~m}$ and $300 \mathrm{~m}$ height levels proportionally to the scattering coefficients for the two height levels, which were measured by the nephelometer (we assume the $\omega_{0}$ for the two height levels are identical within a given hour). The scattering coefficients used in the scattering correction for the PSAP data were corrected for illumination non-idealities according to Anderson and Ogren (1998) and interpolated to $574 \mathrm{~nm}$ using the nephelometer-derived scattering Ångström exponent (Virkkula et al., 2005). Then, the aerosol single scattering albedo at $574 \mathrm{~nm}, \omega_{0}$, was calculated as the ratio of the aerosol light scattering over the 
extinction:

$\omega_{0,574 \mathrm{~nm}}=\frac{\sigma_{\mathrm{sp}, 574 \mathrm{~nm}}}{\sigma_{\mathrm{sp}, 574 \mathrm{~nm}}+\sigma_{\mathrm{ap}, 574 \mathrm{~nm}}}$,

where $\sigma_{\text {ap }}$ is the aerosol absorption measured by PSAP at $574 \mathrm{~nm}$, while $\sigma_{\mathrm{sp}}$ is the interpolated scattering coefficient from the nephelometer.

\subsubsection{Size distribution measurements}

Particle size distributions at ZOTTO are measured with a Differential Mobility Particle Sizer (DMPS). The principle of this instrument has been described previously (Knutson and Whitby, 1975; Winklmayr et al., 1991; Birmili et al., 1999) and detailed information about the ZOTTO DMPS system is given in Heintzenberg et al. (2008, 2011). In short, the ZOTTO DMPS consists of a $28 \mathrm{~cm}$-long Hauke-type Differential Mobility Analyzer (DMA) and a Condensation Particle Counter (CPC, TSI model 3672). The aerosol is neutralized with a corona-discharge-based aerosol neutralizer before sizing. After multiple-charge inversion, size distributions between 15 and $835 \mathrm{~nm}$ dry particle electrical mobility diameter are obtained within 18 logarithmically equal size bins. The sample flow through the particle counter is limited by a critical orifice to $0.78 \mathrm{~L} \mathrm{~min}^{-1}$. The sheath airflow of $5.0 \mathrm{~L} \mathrm{~min}^{-1}$ is circulated in a closed loop, regulated by a computer-controlled air blower with adjustable speed. Along with the switching periods between the 300 and $50 \mathrm{~m}$ height levels, particle mobility distributions are recorded at about 6 min intervals. After inversion of the mobility distributions according to Stratmann and Wiedensohler (1996) the number size distributions were corrected for transmission losses based on the results of the pre-experiment inlet calibration described earlier (Birmili et al., 2007). For further analysis, hourly and daily averages are calculated. A least squares fitting algorithm was used to parameterize the particle number size distribution by a multiple log-normal function (Birmili et al., 2001). The main purpose is to quantitatively describe the particle number size distributions and allow straightforward comparisons between different aerosol particle data sets (Wu et al., 2009). In this study we assumed the existence of at least two modes for our measurement size range $(15 \mathrm{~nm}$ to $835 \mathrm{~nm}$ ), the Aitken mode (smaller than $\sim 100 \mathrm{~nm}$, mode 1 ) and the accumulation mode (larger than $\sim 100 \mathrm{~nm}$, mode 2 ). Occasionally, the agreement between fitted and measured spectra is not perfect for the accumulation mode. In such case, an additional mode ( $>250 \mathrm{~nm}$, mode 3 ) was added to the fitting, which we assume to be either a "droplet mode" from cloud processing, or a very aged accumulation mode.

\subsubsection{Carbon monoxide measurements}

Carbon monoxide $(\mathrm{CO})$ is measured with the vacuum ultraviolet resonance fluorescence technique, employing an Aerolaser Fast-CO-Monitor (Model AL 5002, Aerolaser GmbH, Germany). Prior to measurement, the air is dried using a
Nafion drier. Automated periodic zero and span calibrations are made to account for instrumental drift (every $6 \mathrm{~h}$ for the year 2006 and 2007, every $77 \mathrm{~min}$ since 2008). A natural (ambient air) working standard is used as the span calibration gas at the ZOTTO site. It consists of a $30 \mathrm{~L}$ Scott-Marrin aluminum cylinder (Luxfer) containing pressurized ambient air collected from the rooftop of the Max Planck Institute for Chemistry (MPIC), Mainz in 2003. The CO mixing ratio in this cylinder was determined to be $175.9 \mathrm{ppb} \pm 1.4 \mathrm{ppb}$ against the EMPA-2001 scale in 2005. Quality control of the continuous $\mathrm{CO}$ data was done by a bivariate regression analysis against independently measured data from flask samples, analyzed at the Max Planck Institute for Biogeochemistry for the period from January 2007 to May 2008. The flask results were compared with the continuous $\mathrm{CO}$ measurements averaged to approximately $15 \mathrm{~min}$ (flask sampling time). The bivariate regression analysis (with a total number of 110 samples) revealed a very good agreement between the two independent data sets, with the goodness of fit of 20.55, an intercept of $5.1 \pm 4.2 \mathrm{ppb}$ and a slope of $0.97 \pm 0.03$ ( \pm standard error) (Vasileva et al., 2011). A similar intercept had been obtained for the flask and in-situ data obtained in the BARCA campaign, where the same type of flasks and instrumentation was used (Andreae et al., 2012). A negligibly small offset is therefore obtained at ambient concentrations around typically observed values of $80-200 \mathrm{ppb}$, and we can state that the $\mathrm{CO}$ data provide a reliable basis for further process analyses. The original $\mathrm{CO}$ data, measured with a frequency of $3 \mathrm{~s}$, was converted to $1 \mathrm{~h}$ averages to minimize uncertainties inherent in the data analysis methodology. It needs to be noted that technical problems occurred with our $\mathrm{CO}$ monitor during the following periods, resulting in breaks in the $\mathrm{CO}$ time series (Fig. 1): 24 February to 4 March 2007, 29 May to 9 July 2007, 3 September 2007 to 15 February 2008, 1 June 2008 to 1 October 2009, 30 July to 18 September 2010, 29 December 2010 to 10 April 2011, and after 23 June 2011.

\subsubsection{Other measurements}

The $\mathrm{CH}_{4}$ measurement is performed by an EnviroSense 3000i analyzer (CFADS-17, Picarro Inc., USA) based on the cavity ring-down spectroscopy technique (CRDS) (Crosson, 2008). Details on the instrument setup and data processing can be found in Winderlich et al. (2010). A full set of meteorological instruments is operating at ZOTTO since 2007; the temperature data was used in the discussion of this paper. A detailed description has been given in the supplement to Winderlich et al. (2010).

\subsection{Data analysis methods}

\subsubsection{Estimation of background CO (REBS)}

Sampling at remote monitoring sites (e.g., Siberia) is important for observing the composition of the relatively clean 


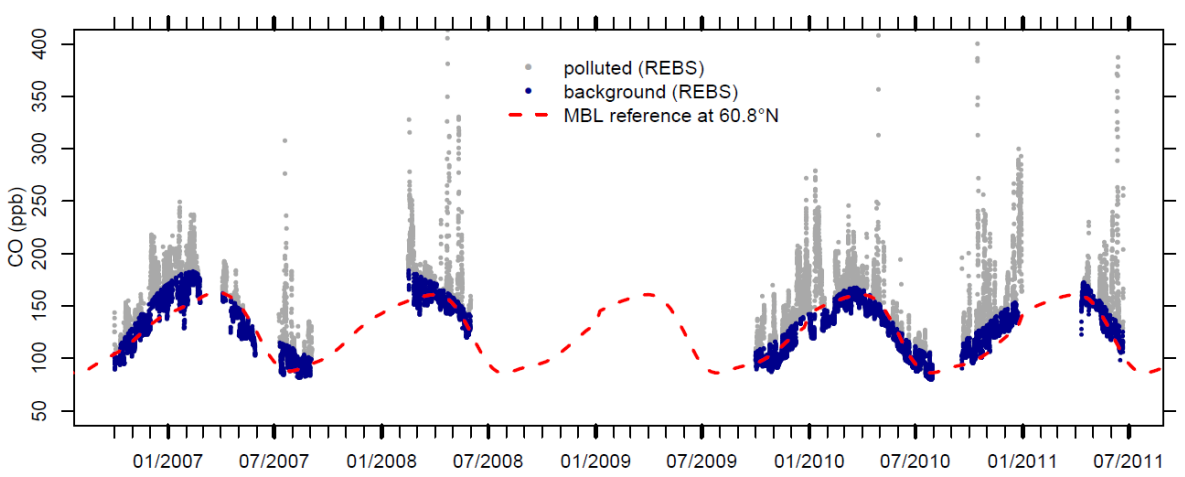

Fig. 1. Time series of hourly mean CO concentration at ZOTTO. For reference, the background CO mixing ratio in the marine boundary layer (MBL) representative of latitude $60.8^{\circ} \mathrm{N}$ is indicated by a red dashed line.

background atmosphere. However, many background monitoring sites are frequently affected by air masses that are influenced by regional emission sources and therefore not representative for well-mixed background air. Data filtering is therefore an important step in analyzing the data. In this paper, we define "background" $\mathrm{CO}$ as the level that would exist without influence of local or regional pollution sources, but is still affected by net uptake or emissions from natural origin as well as pollution transported from very distant sources. To define $\mathrm{CO}$ mixing ratios representing background air (or the other way around to define the polluted periods) we made use of a non-parametric statistical approach named REBS (robust extraction of background signal). This technique has been previously applied for the identification of background $\mathrm{CO}$ concentrations for long-term measurements at the highalpine background site at Jungfraujoch (Ruckstuhl et al., 2012) and at a global background station in China (Zhang et al., 2011a). In our application, we use a bandwidth of three months following the suggestion of Ruckstuhl et al. (2012). Figure 1 shows the time series of the hourly mean CO mixing ratio at ZOTTO, the blue symbols indicate background measurements according to REBS. Measurements that are influenced by polluted air masses are indicated by the grey symbols. For reference, the background $\mathrm{CO}$ mixing ratio in the marine boundary layer representative of latitude $60.8^{\circ} \mathrm{N}$ is indicated by the red dashed line (GLOBALVIEW-CO, 2009).

\subsubsection{STILT model}

To assess CO sources, time-reversed Lagrangian particle dispersion model simulations were made using the Stochastic Time Inverted Lagrangian Transport model STILT (Lin et al., 2003). In this application, STILT was driven by meteorological forecast data from ECMWF (European Center for Medium range Weather Forecasting model) with a time resolution of $3 \mathrm{~h}$ and a grid spatial resolution of $0.25^{\circ} \times 0.25^{\circ}$ for a domain covering Central Siberia (Domain: latitude $50-77^{\circ} \mathrm{N}$; longitude: $55-102^{\circ} \mathrm{E}$ ). From the receptor point (ZOTTO site), an ensemble of 100 particles (air parcels) is released and their back trajectories are followed for 15 days. Footprints (sensitivity of mixing ratios at the receptor site to upstream surface fluxes, in units of ppm per $\mu \mathrm{mol} \mathrm{m}^{-2} \mathrm{~s}^{-1}$ ) are derived from this trajectory ensemble, following Gerbig et al. (2003). By mapping the footprints onto different emission inventories, the contribution of $\mathrm{CO}$ at the receptor point from different upstream sources (anthropogenic and biomass burning in this study) during the given time interval can be obtained.

For anthropogenic $\mathrm{CO}$ simulations, we used anthropogenic emissions based on the Emission Database for Global Atmospheric Research (EDGAR), release version 4.1 (EDGAR-4.1, 2010). Offline time-of-day and day-of-week scaling factors are adapted to account for the time dependence of anthropogenic emission fluxes (Veldt, 2009). The day-of-week factors are 0.83 and 0.67 for Saturday and Sunday and 1.1 for weekdays. Time-of-day factors average to unity, and range from 0.36 in the middle of the night to 1.39 for the rush-hour peak. For simulation of biomass-burning $\mathrm{CO}$, we used the emissions calculated based on the global fire emission database GFED 3.1 (Global Fire Emissions Database, release version 3.1) 3-hourly emission in a global $0.5^{\circ}$ grid (van der Werf et al., 2010). The STILT simulations treat $\mathrm{CO}$ as inert tracer, so no photochemical loss (through reaction with $\mathrm{OH}$ ) or production (from oxidation of biogenic VOC) was taken into account during the time of transport from the domain boundary to the measurement locations.

\subsubsection{Separation of polluted air periods from pristine conditions}

In addition to using REBS, pristine periods were also selected manually, using measured absorption coefficients and observed or model-estimated $\mathrm{CO}$ as criteria, as shown in Fig. 2. The periods associated with low CO and low absorption coefficients are classified as pristine. During these periods, CO mixing ratios rise only a few ppb above the seasonal baseline, and absorption coefficients remain below $1 \mathrm{Mm}^{-1}$. The advantage of this method over REBS is that it provides 


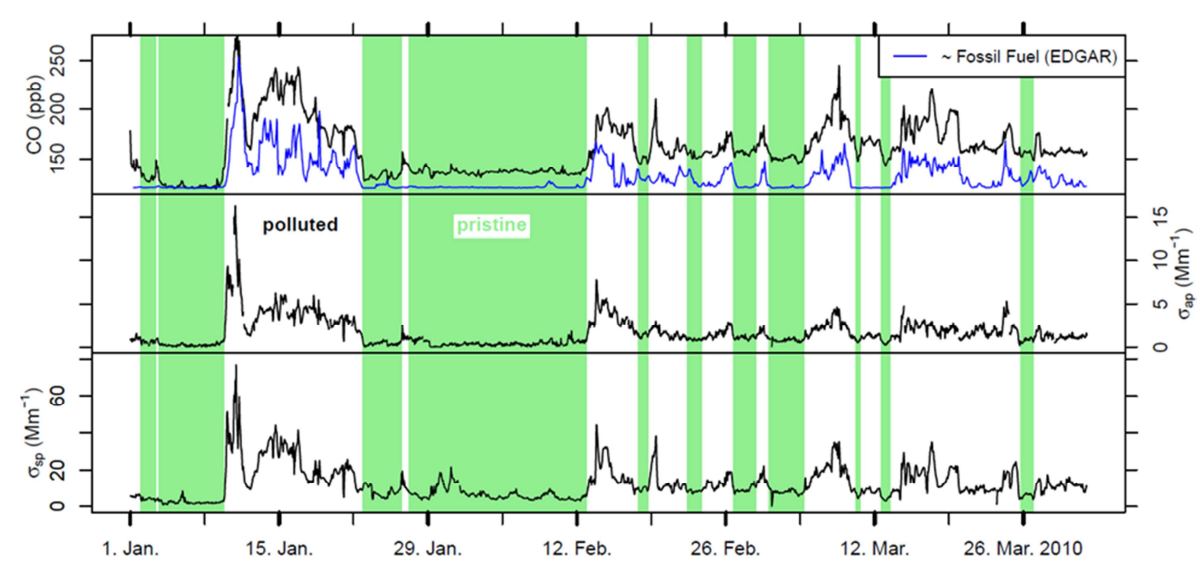

Fig. 2. Example of separation of polluted air periods from pristine conditions. Measured CO concentrations, absorption coefficients, and scattering coefficients during winter 2010 are shown in the upper, middle, and lower figure respectively, and the STILT-model-estimated fossil fuel burning $\mathrm{CO}$ is shown in the upper figure in blue.

much greater data coverage, because we have absorption data for almost the entire study period, whereas the $\mathrm{CO}$ data, which are needed for REBS, have large data gaps due to technical problems. Furthermore, this method allows the selection of clean periods on an absolute basis, while REBS only separates pollution events from a background, which may already be influenced by remote pollution sources.

Obviously, this method is most reliable when all data sets are available. In cases where the $\mathrm{CO}$ measurements are not available, we rely on the EDGAR/GFED3-STILT model. Local emissions from temporally short or spatially small sources (vehicles, small fires) cannot be represented by this model; fortunately, they will show up in the absorption signal, and will be correctly indicated as polluted periods. Another risk for false classification could come from long-range transport. Because the STILT model covers the Siberia domain only and the boundary conditions are set to zero, it does not take the emissions from outside this region into account. Polluted air masses from Europe or Southeast Asia might arrive at ZOTTO, without a STILT CO signal and with a low absorption signal due to long-range transport, and could still influence the particle size distribution and concentration with a pollution signal. This is unlikely, however, because soot carbon would not be removed by wet deposition faster than other aerosol components, and consequently the absence of detectable absorption by soot carbon implies that other pollution particles would also have been removed during transport, returning the aerosol burden to a near-pristine state.

\subsubsection{Estimation of hygroscopicity factor and $\mathrm{CCN}_{0.4}$ concentration}

As mentioned in the introduction, the hygroscopicity factor, $\kappa$, is used to describe the influence of the chemical composition on the CCN activity of aerosol particles. It has been shown that $\kappa$ is zero for insoluble materials like soot or min- eral dust, about 0.1 for SOA, around 0.6 for ammonium sulfate and nitrate, and around $0.95-1$ for sea salt (Rose et al., 2010). The $\kappa$ value of mixed aerosol can be approximated by a linear combination of the $\kappa$ values of the individual chemical components weighted by mass fractions, assuming that the densities of the individual components are similar to the overall particle density (Kreidenweis et al., 2008, 2009). Gunthe et al. (2009) suggested that the $\kappa$ value in the Amazon wet season could be parameterized as a function of AMS-based organic mass fraction $\left(f_{\text {org }}\right)$ and inorganic mass fractions $\left(f_{\text {inorg }}\right)$ :

$\kappa=\kappa_{\text {org }} \times f_{\text {org }}+\kappa_{\text {inorg }} \times f_{\text {inorg }}$,

where $\kappa_{\text {org }} \approx 0.1$ which can be regarded as the effective hygroscopicity of biogenic SOA, and $\kappa_{\text {inorg }} \approx 0.6$, which is representative for ammonium sulfate and related salts. Using the values of $\kappa$ given above, the lower cutoff diameter for $\mathrm{CCN}$ at a supersaturation of $0.4 \%$ (a value commonly used for convective clouds) was calculated using the relationship between the critical diameter, supersaturation, and $\kappa$ (Petters and Kreidenweis, 2007; Su et al., 2010). The organic mass fraction $\left(f_{\text {org }}\right)$ and inorganic mass fraction $\left(f_{\text {inorg }}\right)$ were calculated based on results from organic carbon/elemental carbon (OC/EC) analysis and ion chromatography (IC) analysis of filter samples. The organic matter (OM) mass was estimated from the OC mass by multiplication with a factor of $1.7\left(\mathrm{OM}=1.7^{*} \mathrm{OC}\right)$. The inorganic mass was calculated as the sum of the dominant ionic species $\mathrm{NH}_{4}^{+}, \mathrm{NO}_{3}^{-}$, and $\mathrm{SO}_{4}^{2-}$. A detailed presentation and discussion of the OC/EC and IC measurement results will be given by Chi et al. (2013). Because the sampling duration for filter sampling at ZOTTO was quite long (on average 5 days), the air mass during sampling periods may change significantly. Therefore, most filters cover both pristine and polluted periods. Only a few filters ("clean filters") were collected entirely during pristine periods. Due to this limitation, seasonal averages of $f_{\text {org }}$ and 
Table 1. Median and range, average and standard deviation of scattering coefficient, backscattering coefficient, Ångström exponent, backscattering ratio, absorption coefficient, single scattering albedo, and $\mathrm{CO}$ for $50 \mathrm{~m}$ and $300 \mathrm{~m}$ height levels at ZOTTO.

\begin{tabular}{|c|c|c|c|c|c|}
\hline & & \multicolumn{2}{|c|}{$50 \mathrm{~m}$} & \multicolumn{2}{|c|}{$300 \mathrm{~m}$} \\
\hline & & Median (min-max) & Mean \pm STD & Median (min-max) & Mean $\pm \mathrm{STD}$ \\
\hline \multirow{4}{*}{$\begin{array}{l}\text { Scattering } \\
\text { coefficient } \\
\left(\sigma_{\mathrm{sp}}, \mathrm{Mm}^{-1}\right)\end{array}$} & $450 \mathrm{~nm}$ & $16.48(0.03-2569)$ & $22.14 \pm 25.48$ & $14.78(0.03-885)$ & $20.34 \pm 22.19$ \\
\hline & $550 \mathrm{~nm}$ & $11.44(0.03-1823)$ & $15.49 \pm 17.92$ & $10.33(0.03-632)$ & $14.23 \pm 15.60$ \\
\hline & $700 \mathrm{~nm}$ & $7.19(0.03-1152)$ & $9.81 \pm 11.26$ & $6.49(0.03-385)$ & $9.02 \pm 9.75$ \\
\hline & $574 \mathrm{~nm}$ & $10.66(0.02-1700)$ & $14.45 \pm 16.70$ & $9.61(0.02-590)$ & $13.27 \pm 14.54$ \\
\hline \multirow{3}{*}{$\begin{array}{l}\text { Backscattering } \\
\text { coefficient } \\
\left(\sigma_{\text {bsp }}, \mathrm{Mm}^{-1}\right)\end{array}$} & $450 \mathrm{~nm}$ & $1.66(-0.80-271)$ & $2.15 \pm 2.52$ & $1.49(-2.57-77)$ & $1.98 \pm 2.13$ \\
\hline & $550 \mathrm{~nm}$ & $1.32(-0.53-209)$ & $1.72 \pm 1.96$ & $1.19(-0.64-62)$ & $1.58 \pm 1.68$ \\
\hline & $700 \mathrm{~nm}$ & $1.07(-0.55-157)$ & $1.37 \pm 1.52$ & $0.96(-1.11-51)$ & $1.26 \pm 1.33$ \\
\hline \multirow{3}{*}{$\begin{array}{l}\text { Ångström } \\
\text { exponent }(\stackrel{a}{)})\end{array}$} & $450 / 550$ & $1.73(-30-15.1)$ & $1.71 \pm 0.60$ & $1.78(-29-17.5)$ & $1.75 \pm 0.67$ \\
\hline & $550 / 700$ & $1.98(-12.1-6.7)$ & $1.93 \pm 0.61$ & $1.99(-48.5-5.2)$ & $1.92 \pm 0.72$ \\
\hline & $450 / 700$ & $1.89(-12.3-4.8)$ & $1.84 \pm 0.47$ & $1.90(-12.2-5.2)$ & $1.85 \pm 0.49$ \\
\hline \multirow{3}{*}{$\begin{array}{l}\text { Backscattering } \\
\text { ratio }(b)\end{array}$} & $450 \mathrm{~nm}$ & & $0.098 \pm 0.005$ & & $0.104 \pm 0.009$ \\
\hline & $550 \mathrm{~nm}$ & & $0.112 \pm 0.009$ & & $0.117 \pm 0.009$ \\
\hline & $700 \mathrm{~nm}$ & & $0.143 \pm 0.016$ & & $0.150 \pm 0.016$ \\
\hline $\begin{array}{l}\text { Absorption } \\
\text { coefficient } \\
\left(\sigma_{\text {ap }}, \mathrm{Mm}^{-1}\right)\end{array}$ & $574 \mathrm{~nm}$ & $1.15(0.00-173)$ & $1.87 \pm 2.54$ & $1.02(0.00-108)$ & $1.74 \pm 2.40$ \\
\hline $\begin{array}{l}\text { Single scattering } \\
\text { albedo }\left(\omega_{0}\right)\end{array}$ & $574 \mathrm{~nm}$ & $0.88(0.01-1.00)$ & $0.88 \pm 0.08$ & $0.88(0.01-1.00)$ & $0.88 \pm 0.08$ \\
\hline $\mathrm{CO}(\mathrm{ppb})$ & & $143.3(80.06-920)$ & $143.44 \pm 35.78$ & $136.7(80.01-810)$ & $140.20 \pm 37.78$ \\
\hline
\end{tabular}

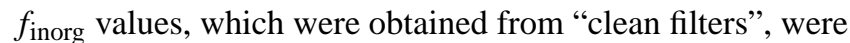
used in the $\kappa$ value calculation. The corresponding cloud condensation nuclei at $0.4 \%$ supersaturation $\left(\mathrm{CCN}_{0.4}\right)$ concentrations were calculated as the number concentration of particles larger than this lower cutoff diameter.

\section{Results and discussion}

\subsection{Aerosol optical properties}

A statistical summary of measured and calculated aerosol optical properties at the ZOTTO site for the period of October 2006 to December 2011 at both height levels is given in Table 1. All statistical parameters are computed based on hourly averaged data. The absorption and scattering coefficients show large variations in the observed values at both the $50 \mathrm{~m}$ and $300 \mathrm{~m}$ levels. For instance, the hourly values at $50 \mathrm{~m}$ elevation for $\sigma_{\text {ap }}$ at $574 \mathrm{~nm}$ span several orders of magnitude. They vary from a minimum of nearly zero during a clean period in September 2008 up to a maximum of $173 \mathrm{Mm}^{-1}$ for an episode strongly influenced by nearby biomass burning in July 2007 (details for this episode will be discussed in Sect. 3.3.2).

The medians and averages suggest, however, that the aerosol sampled at ZOTTO during our study period were generally representative of a fairly clean region. Our average values for the total scattering coefficient $\left(\sigma_{\mathrm{sp}}\right)$ and the back scattering coefficient $\left(\sigma_{\mathrm{bsp}}\right)$ at the ZOTTO site are comparable to those measured at other high latitude Northern Hemisphere remote sites using the same type of instrument (TSI 3563), including three years of measurements at Barrow, Alaska (Delene and Ogren, 2002), and three years of measurements made at Pallas, in northern Finland (Aaltonen et al., 2006). Much larger scattering coefficients (typically by 1-2 orders of magnitude) have been measured at sites affected by urban or continental pollution (Cabada et al., 2004; Vrekoussis et al., 2005; Garland et al., 2009). Our average absorption coefficients $\left(\sigma_{\mathrm{ap}}\right.$ at $\left.574 \mathrm{~nm}\right)$ derived from PSAP are also comparable to those measured at the Barrow site and in marine environments (Anderson et al., 1999; Fujitani et al., 2007). If we apply the commonly used mass absorption efficiency $\left(\alpha_{\text {abs }}\right)$ of $10 \mathrm{~m}^{2} \mathrm{~g}^{-1}$ to our absorption data, the resulting mean equivalent $\mathrm{BC}\left(\mathrm{BC}_{\mathrm{e}}\right)$ averages are $0.19 \mu \mathrm{g} \mathrm{m}^{-3}$ and $0.17 \mu \mathrm{g} \mathrm{m}^{-3}$ for the $50 \mathrm{~m}$ and $300 \mathrm{~m}$ height levels, respectively, which are in the lower range of literature $\mathrm{BC}_{\mathrm{e}}$ concentrations observed at background sites in Europe (Putaud et al., 2004; Yttri et al., 2007; Hyvarinen et al., 2011). For both scattering and absorption coefficients, the concentrations are slightly higher at $50 \mathrm{~m}$ than at $300 \mathrm{~m}$ (up to about $10 \%$ ). Simple vertical dispersion of aerosol could be the reason for this 
difference, and at the same time, we cannot rule out influences by local aerosol from nearby ground sources.

Monthly statistics of measured and derived aerosol optical properties based on all valid hourly average data were analyzed for their seasonal cycle. Similar seasonal cycle trends were observed at both $50 \mathrm{~m}$ and $300 \mathrm{~m}$ height levels for both scattering and absorption data. Figure 3 shows the seasonal cycles for selected parameters at $300 \mathrm{~m}$. The absorption coefficient shows a smooth seasonal variation with a high winter maximum and a broad summer minimum. In contrast, the scattering and backscattering coefficients (not shown) display a much weaker seasonal cycle with a double maximum in winter and summer and a minimum in fall, which is similar to the seasonal cycle for the particle volume concentrations observed at the same site (Heintzenberg et al., 2011). Since the aerosol absorption is strongly related to combustion processes, we hypothesize that the winter maxima in aerosol absorption, scattering, and volume concentrations are due to northern hemispheric fossil fuel combustion. The seasonally integrated STILT footprint suggests that in winter the ZOTTO site is under relatively strong influence from cities (anthropogenic BC sources) located to the south and southwest of the ZOTTO site, e.g., Krasnoyarsk, Novosibirsk, and Omsk. The results from the ion chromatography analysis of filter samples suggest a winter maximum in secondary inorganic ions (sulfate, nitrate, and ammonium), which indicate anthropogenic emissions and contribute to light scattering. Additionally, the higher static stability of the lower troposphere in winter may play a role in the winter maximum by keeping aerosol trapped in a shallow boundary layer. The broad summer minimum in aerosol absorption suggests that in general the ZOTTO site is under much less influence from combustion processes in summer, although some outliers (percentiles > 95\%) with extremely high absorption coefficients indicate the occurrence of elevated concentrations in April, May, July, and October, which are most likely related to biomass burning (forest fires and agricultural burning) in Siberia during those months. In contrast, and simultaneous to the broad minimum of absorption, elevated values of scattering coefficients and sub-micrometer particle number and volume concentrations were observed in summer. This suggests that there are specific aerosol sources in summer that produce non- or only weakly absorbing particles. Biogenic aerosol emission and biogenic SOA formation could be such sources in summer in this remote boreal forest region (Tunved et al., 2006). Given the much deeper mixing layer in summer than in winter, the fact that the values of the scattering coefficient in summer are comparable to those in winter implies a much higher column burden in summer. This indicates that the primary biogenic sources and/or SOA formation in summer are quite strong particle sources in this region.

The weekly and diurnal statistics of measured and derived aerosol optical properties were investigated separately for the different seasons. No clear weekly cycle for either

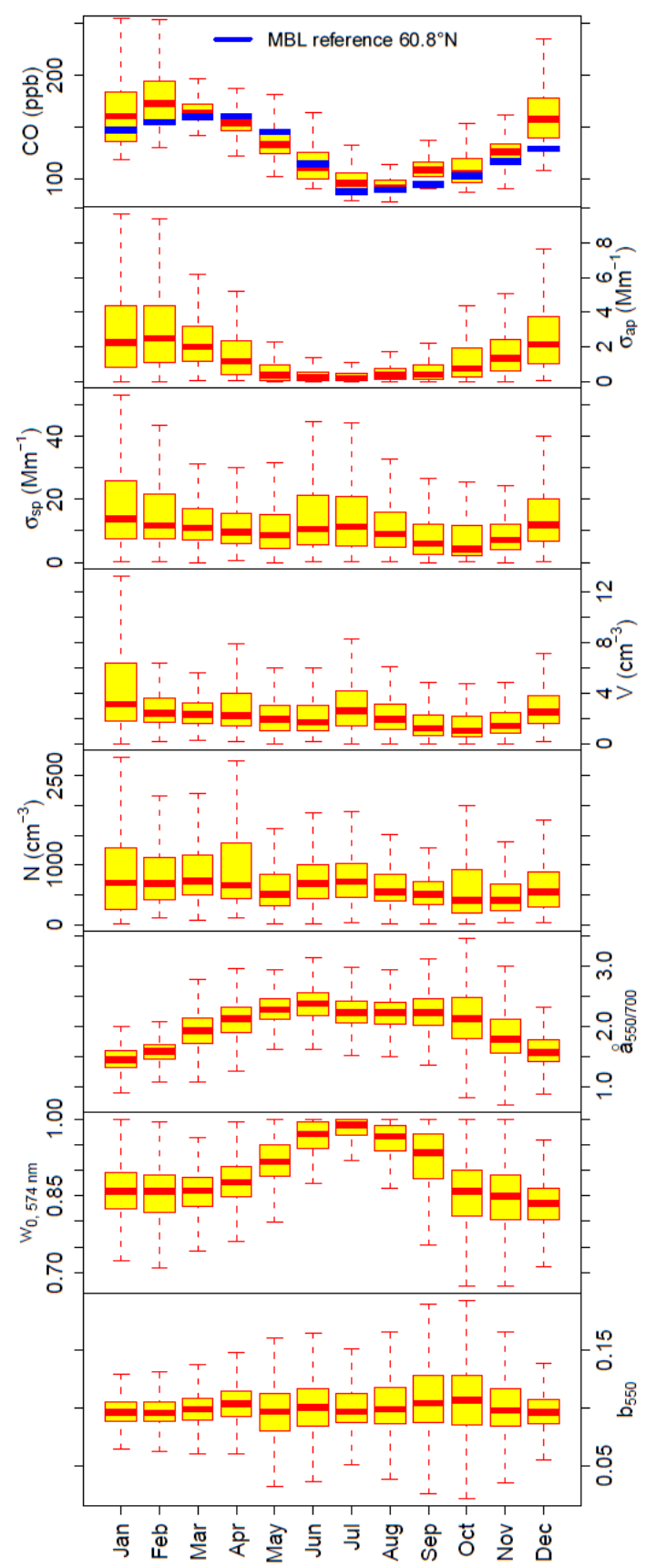

Fig. 3. Seasonal variation of hourly average $\mathrm{CO}$ mixing ratios, aerosol absorption coefficients, aerosol scattering coefficients, volume concentration, number concentration, the Ångström exponent (a) for scattering, single scattering albedo $(574 \mathrm{~nm})$ and backscattering ratio $(550 \mathrm{~nm})$ for $300 \mathrm{~m}$ at ZOTTO from October 2006 to December 2011.

aerosol absorption or scattering was found in any season. Also, there is no clear diurnal cycle for aerosol absorption; Fig. $4 \mathrm{~g}$ and $\mathrm{h}$ give the diurnal variation of the hourly aerosol absorption coefficients in summer and winter, respectively, as example. This is consistent with the assumption that most 
light absorbing particles at this site are from regional or longrange transport, not from local sources. For scattering, diurnal variations are only evident in summer. The diurnal distributions of hourly scattering coefficients in summer for the wavelength of $550 \mathrm{~nm}$ at both sampling heights are shown in Fig. 4. (Figure 4a gives the median and interquartile range of the absolute concentration. The normalized scattering coefficients (hourly divided by daily average values) are shown in Fig. 4b.) For both absolute and normalized scattering coefficients, clear diurnal variations were found in summer, with different variation patterns at the two height levels. For $50 \mathrm{~m}$, the scattering coefficients show two maxima. The main diurnal maximum was found in the morning around 07:0008:00 LT, and a relatively smaller maximum occurred in the evening around 20:00-21:00 LT. This diurnal variation looks like a quite typical diurnal cycle at ground level governed by boundary layer evolution. At $300 \mathrm{~m}$, the diurnal variations are less apparent, with a mid-day maximum occurring a few hours later than the $50 \mathrm{~m}$ morning maximum. Similar diurnal patterns have been found at some mountain (ridge-top) sites (Gebhart et al., 2001), and are mainly due to the boundary layer development and the upward transport of pollution from lower levels during mid-day.

In contrast to aerosol scattering, no diurnal variation in absorption is detectable at ZOTTO (Fig. 4g and h). This difference is likely due to the partially different sources for scattering and absorbing particles, especially in summer. The absorbing particles come from distant combustion sources and are mixed homogeneously in the PBL (planetary boundary layer) by the time they arrive at ZOTTO. In contrast, the scattering particles originate at least in part from near-surface primary or secondary biogenic sources causing a diurnal cycle related to PBL mixing processes. Humidity effects on the particle scattering coefficient cannot explain the observed diurnal variations, as the humidity inside the nephelometer did not exceed $50 \%$ in summer and $10 \%$ in winter. The fact that the particle number concentration increases at ZOTTO at the same time as the scattering and mass (Wiedensohler et al., 2009) suggests that surface sources, PBL mixing effects, new particle formation and aerosol growth by ageing may all play significant roles. Both particle number and mass (scattering) start to decrease after 08:00-09:00 indicating the onset of dilution by a deepening of the PBL.

The statistics for the scattering Ångström exponent $(\stackrel{a}{)}$, back scattering ratio $(b)$, and single scattering albedo $\left(\omega_{0}\right)$ values are listed in Table 1, and the seasonal variations for $a(550 / 700), b(550 \mathrm{~nm})$, and $\omega_{0}(574 \mathrm{~nm})$ are shown in Fig. 3. Our median and mean values for the three pairs of scattering Ångström exponents are comparable to those reported by Aaltonen et al. (2006) at Pallas. Our values for $\stackrel{a}{a}(550 / 700)$ are similar to those observed for $\mathrm{PM}_{10}$ at two anthropogenically influenced continental stations, namely BND (Bondville, Illinois) and SGP (Lamont, Oklahoma), but much higher than those observed at the remote BRW (Barrow, Alaska) site, which is under the strong influence of ma- rine aerosols (Delene and Ogren, 2002). All three pairs of $\stackrel{a}{a}$ show the same seasonal variation, with a minimum in winter and a maximum in summer (peak in June). The exponent $\stackrel{a}{a}$ can be used to infer information about the size of the particles, as it relates inversely to particle size (Russell et al., 2010). A large å implies a particle size distribution with scattering dominated by submicrometer particles, while a distribution dominated by coarse particles typically has a smaller $a$ (Seinfeld and Pandis, 1998). Based on the observed val-

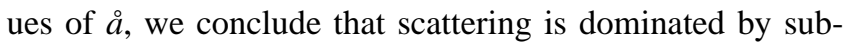
micrometer particles at ZOTTO, especially during summer. Similar values of $\stackrel{a}{ }$ were found at $50 \mathrm{~m}$ and $300 \mathrm{~m}$, which is consistent with the results of Heintzenberg et al. (2011).

It can be seen from Table 1 that the backscattering ratio (b) increased with increasing wavelength. This is due to decreasing size parameters in Mie theory $(2 \pi r / \lambda, r$ is the particle diameter, $\lambda$ is the wavelength), which results in the scattering phase function moving backward when particle size decreases or wavelength increases. Compared to the results of Delene and Ogren (2002), our $b$ at $550 \mathrm{~nm}$ is somewhat higher than the value observed at the remote BRW site, and lower than those observed at anthropogenically dominated sites. Our backscatter ratios show a weak seasonal variation with higher values observed in summer and lower values in winter, with this variation being more pronounced at $700 \mathrm{~nm}$ (not shown).

The differences in the seasonal variation for absorption and scattering result in a clear seasonal cycle for the single scattering albedo $\left(\omega_{0}\right)$ (Fig. 3), with a maximum in summer. Our average single scattering albedo in winter $(0.85)$ is slightly lower than the winter $\omega_{0}(0.86)$ found by Virkkula et al. (2011) at the SMEAR II station in Hyytiälä, Finland, for the period from October 2006 to May 2009. In contrast, our average value in summer (0.96) is higher than their summer value (0.91), suggesting a lower impact of anthropogenic sources at ZOTTO than at SMEAR II. The relatively high difference between summer and winter values indicates a strong secondary aerosol formation during summertime at ZOTTO. The overall mean $\omega_{0}(0.88)$ at ZOTTO is much lower than the mean $\omega_{0}$ found at the remote BRW site, and is also lower than that observed at a forest site (ALMOR) in Norway (Mogo et al., 2012), which is mainly due to relatively higher aerosol absorption at ZOTTO. The monthly median $\omega_{0}$ observed at ZOTTO in winter (0.77-0.89) is comparable to values found at rural and even urban locations (Garland et al., 2008). This is consistent with our earlier conclusion that the ZOTTO site is under the influence of regional anthropogenic sources much of the time, especially during the winter season.

\subsection{CO mixing ratios}

The overall statistical summary of $\mathrm{CO}$ mixing ratios observed at the $50 \mathrm{~m}$ and $300 \mathrm{~m}$ heights at ZOTTO is shown in Table 1. It is interesting to compare our results with other published results on continuous measurements of near 

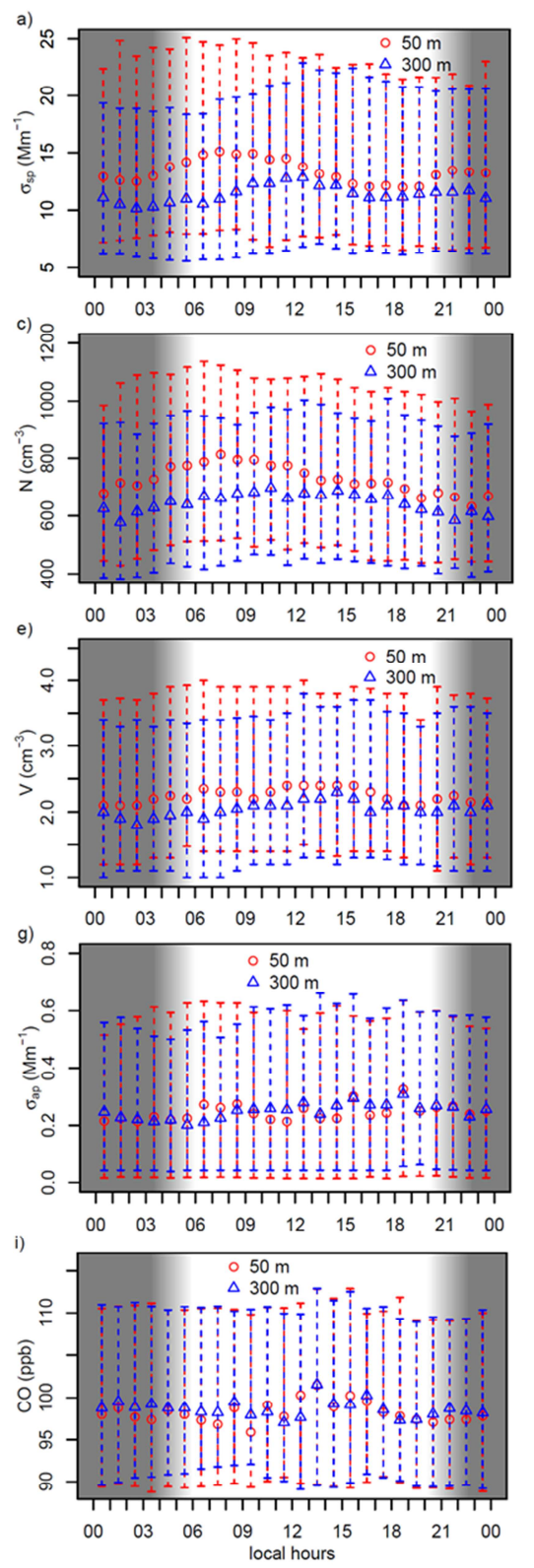
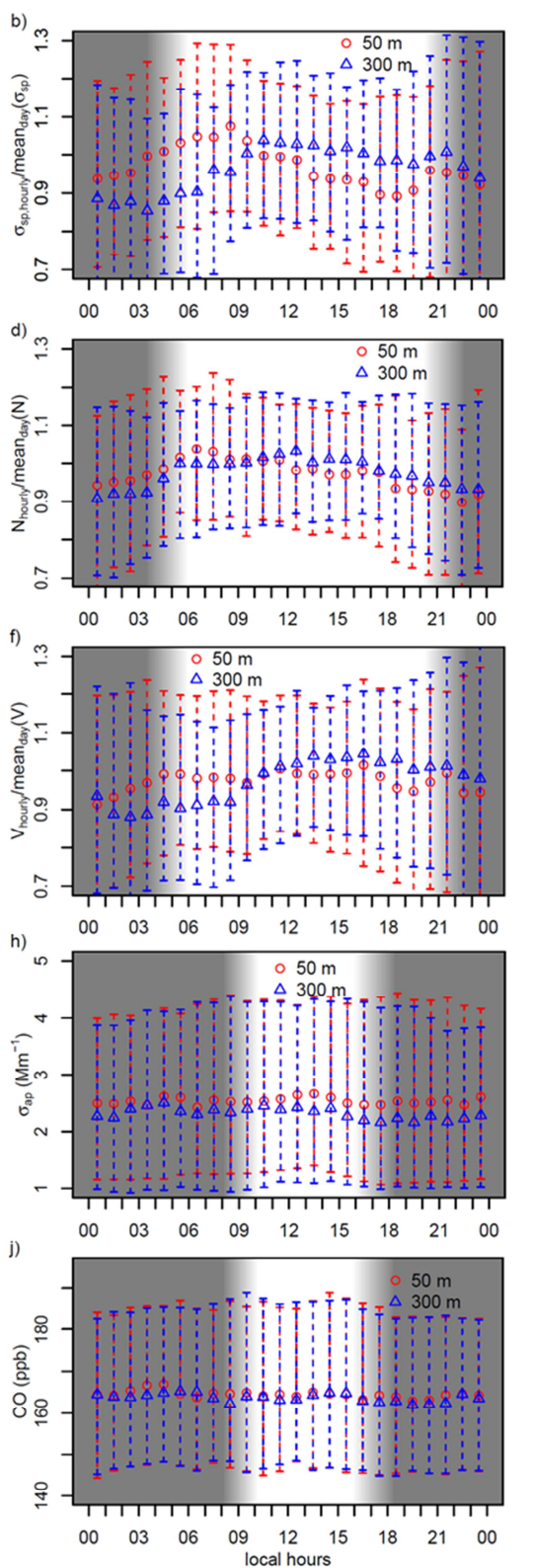

Fig. 4. Diurnal variation of (a-b) aerosol scattering coefficients, (c-d) total number concentration, and (e-f) total volume concentration: (a, c, e) give absolute concentration and $(\mathbf{b}, \mathbf{d}, \mathbf{f})$ are normalized concentration (hourly value divided by daily mean value). Diurnal variation of (g-h) aerosol absorption coefficients, and (i-j) CO mixing ratio: $(\mathbf{g}, \mathbf{i})$ for summer and $(\mathbf{h}, \mathbf{j})$ for winter.

surface CO. The nearest NOAA/CMDL CO monitoring site to ZOTTO, at Ulaan Uul, Mongolia (UUM, $44^{\circ} \mathrm{N}, 111^{\circ} \mathrm{E}$, 914 m a.s.l.) (GLOBALVIEW-CO, 2009) shows an average of $148 \pm 24 \mathrm{ppb}$ for the period from October 2006 to January 2009, which is comparable to our results. Pochanart et al. (2003) reported a slightly lower annual average of $127 \pm 20 \mathrm{ppb}$ at Mondy, a remote high-mountain observatory site in eastern Siberia $\left(51^{\circ} 39^{\prime} \mathrm{N}, 100^{\circ} 55^{\prime} \mathrm{E}\right)$ during $1997-$ 1999. The lower mixing ratios at Mondy can be explained by the relatively high elevation of that station (about $2000 \mathrm{~m}$ above sea level) and the fact that it is less affected by an- thropogenic $\mathrm{CO}$ emissions from regional sources due to its geographic location (Vasileva et al., 2011).

The time series of CO mixing ratios (Fig. 1) shows high variability. It consists of a seasonally varying background signal (determined by REBS and comparable to remote marine background signals) superimposed by regional pollution, which is mainly due to polluted air parcels coming from fossil fuel emission regions or biomass-burning emissions. The pollution frequency (fraction of data showing signs of pollution) is summarized for each season in Table 2. It is highest in winter, when fossil fuel emissions dominate the 
Table 2. Enhancement of $\mathrm{CO}$ estimated from REBS baseline $\left(\mathrm{CO}_{\text {net }}=\mathrm{CO}-\mathrm{CO}_{\text {baseline, rebs }}\right)$ and $\sigma_{\text {ap }}$ to $\mathrm{CO}_{\text {net }}$ ratios (only for $\mathrm{CO}$ polluted episodes) for the $50 \mathrm{~m}$ height level as derived from hourly average values from October 2006 to December 2011.

\begin{tabular}{lcr}
\hline Season & Pollution frequency & $\begin{array}{r}\mathrm{CO}_{\text {net }}(\mathrm{ppb}) \\
\text { Median (min-max) }\end{array}$ \\
\hline Spring & $19 \%$ & $9.6(0.01-295)$ \\
Summer & $20 \%$ & $22.4(0.06-769)$ \\
Fall & $16 \%$ & $8.0(0.02-42)$ \\
Winter & $47 \%$ & $22.4(0.05-155)$ \\
\hline
\end{tabular}

$\mathrm{CO}$ signal and $\mathrm{CO}$ reaches an enhancement of $22 \mathrm{ppb}$ above background $\left(\mathrm{CO}_{\text {net }}\right)$. An almost identical enhancement is true for the summer period, although the pollution frequency is much lower. This suggests that the CO intensity is higher in some summer pollution events.

The seasonal cycle of $\mathrm{CO}$ is characterized by a maximum in late winter (January and February) and a minimum in late summer (Fig. 3). It is similar to that of the aerosol absorption coefficient $\left(\sigma_{\mathrm{ap}}\right)$, which is consistent with the fact that both $\mathrm{BC}$ and $\mathrm{CO}$ are tracers for combustion processes. As is also the case for absorption, the higher $\mathrm{CO}$ in winter may be due to the higher static stability of the lower troposphere and higher anthropogenic emissions from heating. In addition, the lower summer CO signal (about $80 \mathrm{ppb}$ lower than during winter), is partly due to the much shorter lifetime of $\mathrm{CO}$ in summer because of faster photochemical turnover rates (Jaffe et al., 1998; Novelli et al., 1998). Moreover, due to its relatively long lifetime (compared to $\mathrm{BC}$ ) in the atmosphere, $\mathrm{CO}$ has a substantial background concentration, which ranges from $92 \mathrm{ppb}$ in summer up to $160 \mathrm{ppb}$ in early spring (Table 3).

Unlike for the aerosol properties, we did not observe any diurnal variation in the $\mathrm{CO}$ mixing ratios (Fig. $4 \mathrm{i}$ and $\mathrm{j}$ ). It can also be seen from Table 1 and Fig. 4 that there is no significant difference in $\mathrm{CO}$ mixing ratios between the two different height levels. This is consistent with earlier findings from Kozlova et al. (2008), in which no diurnal variation and vertical gradient were found for $\mathrm{CO}$ at the ZOTTO site. This suggests that there are in general no strong local sources for $\mathrm{CO}$ around ZOTTO.

\subsection{Characterization of polluted air}

Using the manual selection method described in Sect. 2.3.3, the entire ZOTTO data set was separated into polluted and pristine periods. The seasonal average and associated standard deviation of selected parameters during these two periods are shown in Table 3. It can be seen that the differences between polluted and pristine periods for $\mathrm{CO}$ and $\sigma_{\mathrm{ap}}$ are highest in winter, and lowest in summer. To characterize further the emission sources in pollution periods, we investigated the ratios $\mathrm{BC}_{\mathrm{e}} / \mathrm{CO}$, total particle concentration (con- densation nuclei, $\mathrm{CN}$ ) / $\mathrm{CO}$, and $\mathrm{CH}_{4} / \mathrm{CO}$ in both winter and summer. In addition, a few case studies have been examined in detail.

\subsubsection{Polluted winter air}

Combustion processes emit both $\mathrm{CO}$ and $\mathrm{BC}$, but the emission ratio between $\mathrm{BC}$ and $\mathrm{CO}$ differs by combustion type and condition (Kondo et al., 2006). Therefore, the BC/CO relationship has been used to distinguish different pollution sources in case studies (Wang et al., 2011; Kondo et al., 2011; Kaiser et al., 2012). Here, we use the $\mathrm{BC}_{\mathrm{e}}$ to $\mathrm{CO}$ relationship observed at the ZOTTO site as an additional indicator of the origin of emissions. We obtain the enhancement ratio $\left(\triangle \mathrm{BC}_{\mathrm{e}} / \triangle \mathrm{CO}\right)$ from the slopes of $\mathrm{BC}_{\mathrm{e}}$ (derived from the light absorption coefficient using a mass absorption efficiency of $10 \mathrm{~m}^{2} \mathrm{~g}^{-1}$ ) and $\mathrm{CO}$, using reduced-major-axis regression (Warton and Weber, 2002), which treats the two variables as symmetrical.

The overall slope $\left(\Delta \mathrm{BC}_{\mathrm{e}} / \Delta \mathrm{CO}\right)$ for all polluted periods in winter is $9.3 \mathrm{ng} \mathrm{m}^{-3} \mathrm{ppb}^{-1}$ with $R^{2}=0.55$, which is higher than values normally found at rural sites (Kondo et al., 2006; Wang et al., 2011) and even at the higher end of the literature range for cities in Asia (Verma et al., 2011; Wang et al., 2011). If we assume that the pollution at ZOTTO mainly comes from anthropogenic emissions in Siberian cities, our data suggests that those emissions have a higher $\mathrm{BC} / \mathrm{CO}$ emission ratio than known from other cities in the literature. A reason could be the high rates of coal or biofuel burning for heating and diesel traffic emissions in the Siberian cities.

In addition to the overall slope, the slopes and correlations for individual events were also checked. It was found that the $\Delta \mathrm{BC}_{\mathrm{e}} / \triangle \mathrm{CO}$ ratio was different for air masses from different source regions. Hence, we separated the data into three regions depending on the dominating airflow direction (based on STILT footprint calculations): south, southwest, and the rest (see Fig. 5a-c). In air from the southern region, large enhancements in $\mathrm{CO}$ and absorption can be related to air transport directly from the industrialized region around Krasnoyarsk (Fig. 5a). The $\mathrm{BC}_{\mathrm{e}}$ to $\mathrm{CO}$ correlations have a generally higher slope for the air from the southern (Fig. $5 \mathrm{~g}$ ) than from southwestern directions Fig. 5h. This might suggest different emission sources from these two regions, with even more diesel traffic emissions or domestic fuel burning in the southern region. However, the observed $\Delta \mathrm{BC}_{\mathrm{e}} / \Delta \mathrm{CO}$ ratio depends not only on emission characteristics, but also on atmospheric processes that influence the two species differentially. For example, wet and dry deposition can affect BC but not $\mathrm{CO}$, whereas chemical reaction with $\mathrm{OH}$ radicals affects mostly $\mathrm{CO}$. In our case, the photochemical CO removal can be neglected because of low $\mathrm{OH}$ concentrations in winter. The higher ratio from the south may be partly because the southern emission sources (cities) are closer to ZOTTO than the southwestern ones and thus have a lower chance for BC deposition. Nevertheless, we estimate this effect to be 
Table 3. Mean and standard deviation for CO, absorption coefficient, scattering coefficient, single scattering albedo, Ångström exponent, total aerosol number concentration, $\mathrm{CCN}_{0.4}$ number concentration, and aerosol volume concentration for polluted and pristine air at ZOTTO $(300 \mathrm{~m})$. The frequency of clean periods determined by the manual selection method is indicated in parentheses.

\begin{tabular}{|c|c|c|c|c|c|c|c|c|}
\hline & $\mathrm{CO}$ & $\begin{array}{l}\text { Absorption } \\
\text { coefficient }\end{array}$ & $\begin{array}{l}\text { Scattering } \\
\text { coefficient }\end{array}$ & $\omega_{0}$ & $\begin{array}{c}\stackrel{\circ}{a} \\
(450 / 700)\end{array}$ & $\begin{array}{c}N \\
\text { total }\end{array}$ & $\begin{array}{c}N \\
\mathrm{CCN}_{0.4}\end{array}$ & $\begin{array}{l}\text { Aerosol } \\
\text { volume }\end{array}$ \\
\hline & $\mathrm{ppb}$ & $\mathrm{Mm}^{-1}$ & $\mathrm{Mm}^{-1}$ & & & $\mathrm{~cm}^{-3}$ & $\mathrm{~cm}^{-3}$ & $\mathrm{~cm}^{-3}$ \\
\hline \multicolumn{9}{|l|}{ Spring } \\
\hline Clean $(36 \%)$ & $138 \pm 12$ & $0.51 \pm 0.33$ & $7.7 \pm 6.7$ & $0.91 \pm 0.05$ & $1.94 \pm 0.54$ & $390 \pm 269$ & $228 \pm 148$ & $1.18 \pm 0.78$ \\
\hline Polluted & $160 \pm 32$ & $2.67 \pm 3.19$ & $16.8 \pm 22.0$ & $0.85 \pm 0.08$ & $1.97 \pm 0.35$ & $1082 \pm 965$ & $724 \pm 759$ & $3.73 \pm 6.01$ \\
\hline Background & $155 \pm 14$ & & & & & & & \\
\hline \multicolumn{9}{|l|}{ Summer } \\
\hline Clean $(32 \%)$ & $89 \pm 4$ & $0.12 \pm 0.18$ & $11.7 \pm 11.0$ & $0.98 \pm 0.03$ & $2.17 \pm 0.40$ & $771 \pm 515$ & $439 \pm 304$ & $2.21 \pm 1.84$ \\
\hline Polluted & $103 \pm 41$ & $0.55 \pm 0.93$ & $16.8 \pm 15.7$ & $0.95 \pm 0.04$ & $2.19 \pm 0.33$ & $759 \pm 580$ & $498 \pm 342$ & $2.61 \pm 1.96$ \\
\hline Background & $92 \pm 5$ & & & & & & & \\
\hline \multicolumn{9}{|l|}{ Fall } \\
\hline Clean $(28 \%)$ & $96 \pm 4$ & $0.26 \pm 0.25$ & $4.2 \pm 3.9$ & $0.93 \pm 0.06$ & $1.88 \pm 0.64$ & $525 \pm 538$ & $203 \pm 187$ & $1.44 \pm 1.89$ \\
\hline Polluted & $117 \pm 16$ & $1.61 \pm 2.41$ & $10.6 \pm 9.8$ & $0.86 \pm 0.08$ & $1.90 \pm 0.47$ & $662 \pm 537$ & $401 \pm 364$ & $2.15 \pm 1.98$ \\
\hline Background & $108 \pm 19$ & & & & & & & \\
\hline \multicolumn{9}{|l|}{ Winter } \\
\hline Clean $(23 \%)$ & $139 \pm 14$ & $0.75 \pm 0.58$ & $6.1 \pm 3.6$ & $0.88 \pm 0.07$ & $1.47 \pm 0.43$ & $244 \pm 275$ & $123 \pm 51$ & $1.15 \pm 0.75$ \\
\hline Polluted & $181 \pm 24$ & $3.46 \pm 2.52$ & $18.7 \pm 12.7$ & $0.84 \pm 0.06$ & $1.45 \pm 0.27$ & $843 \pm 547$ & $456 \pm 301$ & $3.83 \pm 4.66$ \\
\hline Background & $148 \pm 21$ & & & & & & & \\
\hline
\end{tabular}

small, since the differences in the transport distances are not very large. It is more likely that the long-range transport of $\mathrm{CO}$ from outside of the domain influences the $\triangle \mathrm{BC} / \triangle \mathrm{CO}$ ratio. With southwesterly winds, $\mathrm{CO}$ from long-range transport from the west may contribute a substantial fraction of the $\mathrm{CO}$ at the ZOTTO site. For example, the MATCH-MPIC model (Model of Atmospheric Transport and Chemistry Max Planck Institute for Chemistry version, Lawrence et al., 2003) suggests that on some winter days (e.g., 14 and 16 January 2010) as much as $50 \mathrm{ppb}$ CO at ZOTTO may originate from Europe (MATCH-MPIC, 2012). It must be pointed out that it is difficult to generalize these ratios, as the source regions are not well defined by the uncertainties in the footprint calculations and the sources are changing over time as well.

For two days in January 2010, flow from the southwestern region was interrupted by a shift in wind direction to the west (Fig. 6b). The footprint for this episode covers the oil and natural gas production sites in the Ob lowlands, which explains the strong signal in the $\mathrm{CH}_{4}$ data (Fig. 6a). Therefore, we also looked into the $\mathrm{CH}_{4}$ to $\mathrm{CO}$ ratios for the south and southwestern regions and found good correlation to the polluted air periods from the southern region (Fig. $5 \mathrm{~g}$ and $\mathrm{h}$ ), but more irregular behavior for southwestern air. Hsu et al. (2010) had also found good correlation between $\mathrm{CH}_{4}$ and $\mathrm{CO}$ at the Mt. Wilson station in California, with a $\Delta \mathrm{CH}_{4} / \Delta \mathrm{CO}$ ratio of 0.55 for the air from Los Angeles County in February.
Our ratio of 1.2 for air from the southern region is about two times higher, indicating a higher diesel consumption and/or a higher contribution of cold starting engines (Nam et al., 2004). The weaker correlations for air from southwestern directions may be due to several outliers with increased $\mathrm{CH}_{4}$ from the oil and natural gas fields in the western direction (like the January 2010 event). For the air of the rest region, we found only a low correlation for $\mathrm{BC}_{\mathrm{e}}$ to $\mathrm{CO}$, and none for $\mathrm{CH}_{4}$ to $\mathrm{CO}$.

In addition to the $\Delta \mathrm{BC}_{\mathrm{e}} / \Delta \mathrm{CO}$ and $\Delta \mathrm{CH}_{4} / \Delta \mathrm{CO}$ ratios, we also inspected the particle number concentration $(\mathrm{CN})$ to $\mathrm{CO}$ ratios during winter pollution. Previous studies have suggested that the ratio of $\Delta \mathrm{CN} / \triangle \mathrm{CO}$ for fresh aerosol from biomass burning is about $30 \pm 15 \mathrm{~cm}^{-3} \mathrm{ppb}^{-1}$ (Guyon et al., 2005; Andreae and Rosenfeld, 2008; Janhäll et al., 2010; Kuhn et al., 2010). Urban emissions, in contrast, have much higher $\Delta \mathrm{CN} / \triangle \mathrm{CO}$ ratios owing to the more efficient combustion and thus lower $\mathrm{CO}$ emissions from vehicles and power plants (Nicks et al., 2003; Kuhn et al., 2010). Due to particle losses by coagulation and other processes during aging, the ratio is smaller for aged aerosol. For aerosol at ZOTTO, the $\Delta \mathrm{CN} / \triangle \mathrm{CO}$ ratio in air masses from the south is about $18.4 \mathrm{~cm}^{-3} \mathrm{ppb}^{-1}$, which is similar to previous results for aged smoke. However, the correlation between $\mathrm{CN}$ and CO is very weak $\left(R^{2}=0.056\right)$, and no correlation is found for air masses from the southwest. In contrast, $\mathrm{CN}$ and $\mathrm{CO}$ 


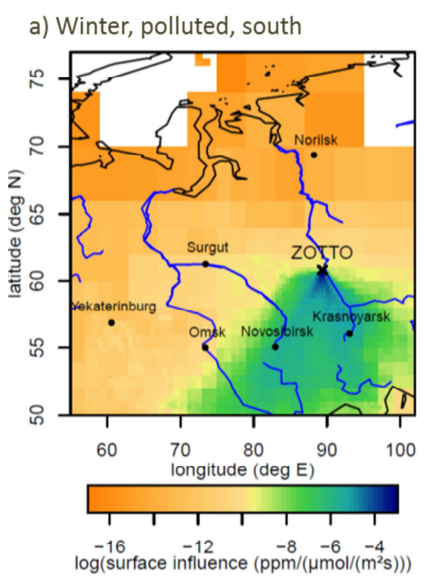

b) Winter, polluted, SW
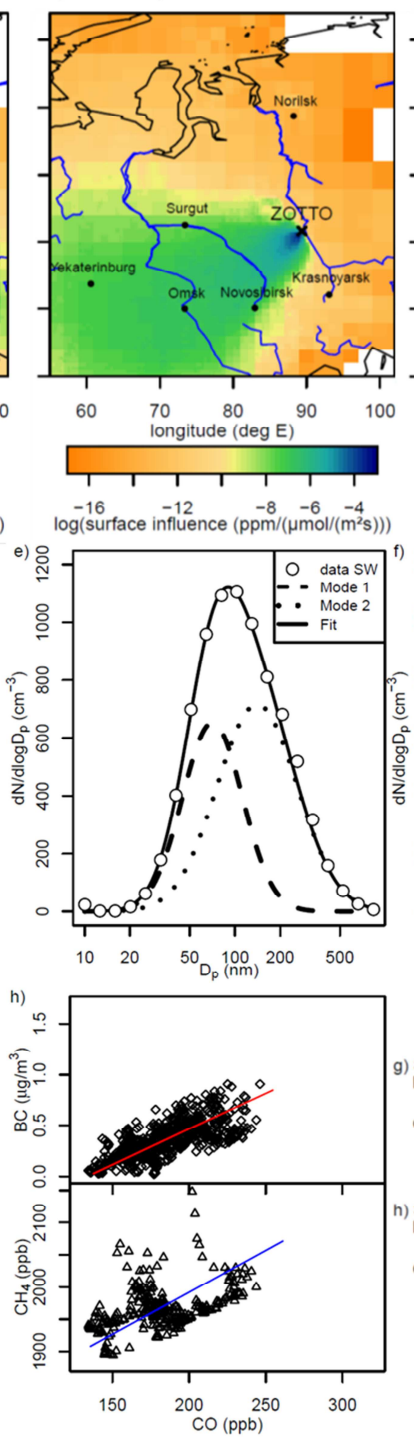

c) Winter, polluted, rest

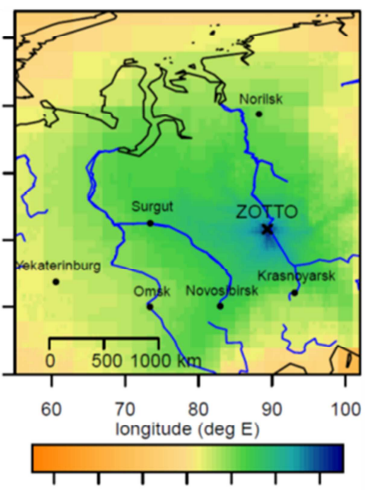

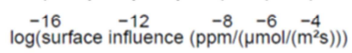

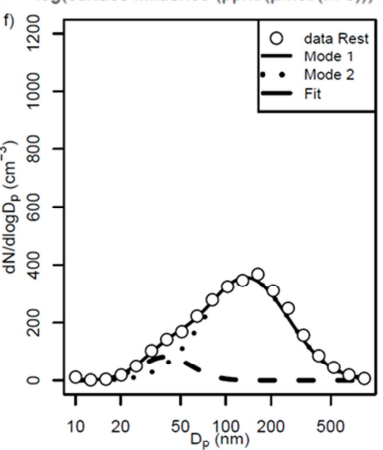

g) South: $\mathrm{BC}^{-3}\left(\mu \mathrm{g} \mathrm{m}^{-3}\right)=0.0112 \times \mathrm{CO} / \mathrm{ppb}-1.68$

$\mathrm{CH}_{4} / \mathrm{ppb}=1.21 \times \mathrm{CO} / \mathrm{ppb}+1702 \mathrm{R}^{2}=0.593$

$R^{2}=0.719$

h) Southwest.

$R^{2}=0.545$

$\mathrm{CH}_{4} / \mathrm{ppb}=1.30 \times \mathrm{CO} / \mathrm{ppb}+1732 \begin{aligned} & R^{2}=0.545 \\ & R^{2}=0.186\end{aligned}$

Fig. 5. Footprints for winter polluted south region (a), winter polluted southwestern region (b), and winter polluted rest region (c); aerosol size distribution for south (d), southwestern (e), and rest regions (f); $\mathrm{BC}_{\mathrm{e}}$ and $\mathrm{CO}, \mathrm{CH}_{4}$ and $\mathrm{CO}$ scatter plots for south (g), and southwestern regions (h).

are well correlated $\left(R^{2}=0.709\right)$ for the rest region (Fig. $\left.5 \mathrm{c}\right)$, and the regression slope $\left(30.8 \mathrm{~cm}^{-3} \mathrm{ppb}^{-1}\right)$ is close to the average value for biomass burning. This would suggest a strong contribution of biofuel burning to the winter air pollution in rural Siberia.

The differences in emission sources can be expected to also affect the other aerosol properties, including the size distribution. Table 4 lists the $\mathrm{CO}$ mixing ratio, $\sigma_{\mathrm{ap}}, \mathrm{CH}_{4}$, and total number concentration from the three regions during the winter pollution periods. Compared to air masses from other regions (rest), higher $\mathrm{CO}$ mixing ratios, absorption coefficients, and number concentrations were observed for the air masses from the south and southwest regions. The number size distributions of particles in polluted winter air from the three different source regions are shown in Fig. 5d-f. The particles from the south and southwest regions show a similar size distribution, with an Aitken mode peak at around $100 \mathrm{~nm}$, which is larger than the typical Aitken mode of "traffic related particles" (Birmili et al., 2001). This may be due to growth of particles during transport, and we also could not rule out influence from biofuel burning, as similar sizes of Aitken mode particles have been observed for emissions from wood stoves (Hedberg et al., 2002). The polluted particles from the other regions (rest) show a wide accumulation mode peak around $160 \mathrm{~nm}$, which can result either from biomass burning, or from long-range transport of pollutants. 

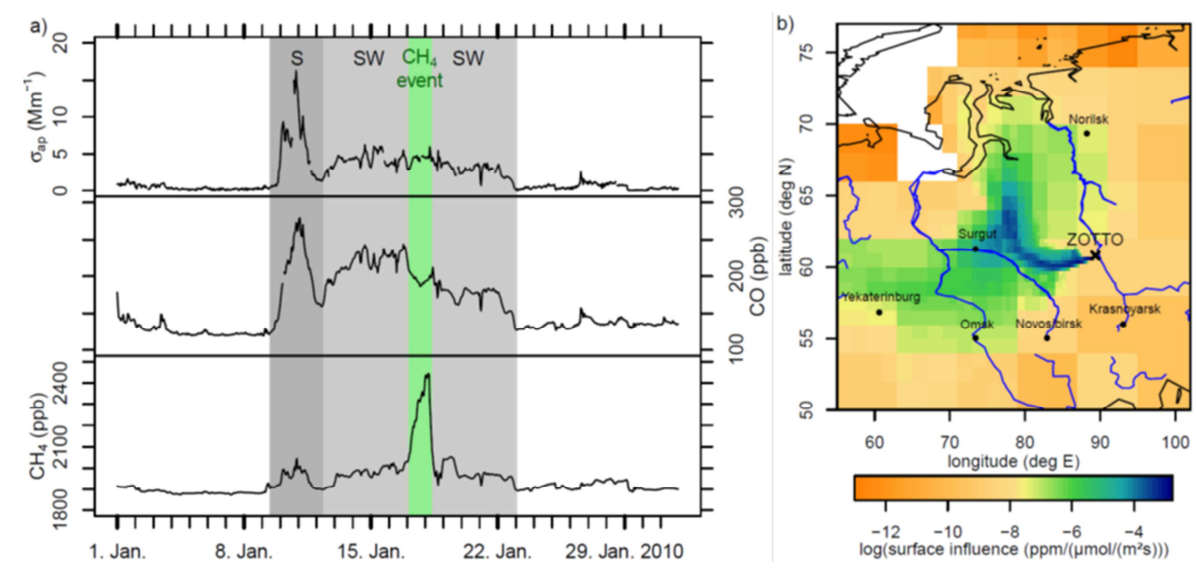

Fig. 6. (a) Time series of $\sigma_{\mathrm{ap}}, \mathrm{CO}$, and $\mathrm{CH}_{4}$ mixing ratios in January 2010 with (b) footprint of $\mathrm{CH}_{4}$ event.

In combination with our $\Delta \mathrm{CN} / \Delta \mathrm{CO}$ ratios, the data suggests that the polluted aerosols from the rest region originate mostly from biofuel combustion.

\subsubsection{Polluted summer air}

The pollution sources in summer are expected to be different from those in winter. On the one hand, large-scale open biomass burning becomes an important and at times even dominant contributor in summer. On the other hand, the contribution from domestic heating should be minimal in this season. In order to see the influence from large-scale, open biomass burning and the effect of changes in anthropogenic sources, we separate summer pollution periods into biomassburning-dominated (BB) periods, anthropogenic-dominated (AN, mostly fossil fuel derived) periods, and mixed periods. The separation is based on the STILT model output for CO. The AN-dominated periods are defined as the periods when STILT's anthropogenic CO contributes more than $70 \%$ of STILT's total CO (anthropogenic + biomass burning). An analogous definition was used for BB-dominated periods. In total, $12 \%$ of the summer pollution periods were classified as BB-dominated, $32 \%$ were classified as AN-dominated, and the rest were mixed periods.

The median number size distributions of the particles during the AN- and BB-dominated periods for summer are shown in Fig. $7 b$ and c. Earlier studies have shown that biomass-burning emissions appear mainly in the accumulation mode: fresh smoke has a count median diameter, $D_{\mathrm{g}}$ (similar to the geometric mean diameter), of around $120 \mathrm{~nm}$ (Reid et al., 1998; Reid and Hobbs, 1998; Guyon et al., 2005), while aged smoke particles are larger, up to $D_{\mathrm{g}}>240 \mathrm{~nm}$ (Anderson et al., 1996a; Reid et al., 1998; Fiebig et al., 2003). Fresh fossil-fuel-related urban particles are normally smaller, with the highest number concentrations in the nucleation and Aitken modes. Accordingly, larger particles were observed during BB-dominated periods (Fig. 7b) than in AN-dominated periods (Fig. 7c). The AN size distri- bution can be separated into two dominant modes, where the smaller one $\left(D_{\mathrm{g}}=\sim 80 \mathrm{~nm}\right)$ relates directly to urban particles. However, particles at ZOTTO are in general aged particles, so for both BB-dominated and AN-dominated periods they have a larger diameter than those from fresh biomass burning and fresh urban particles.

Since the largest difference between summer and winter anthropogenic pollution is the amount of residential heating, one may expect smaller sizes of summer anthropogenic particles since there is a lower contribution of biofuel burning from heating. By comparing the AN-dominated size distribution in summer (Fig. 7b-c) with the polluted size distribution for winter (Fig. 5d-f), we can indeed see that the size in summer AN-dominated periods $(\approx 81 \mathrm{~nm})$ is somewhat smaller than those in winter from south and southwestern regions $(80-100 \mathrm{~nm})$. This small difference may be also partly explained by additional biogenic emissions in summer, when fresh anthropogenic particles grow through the deposition of SOA material and the conditions generally favor secondary particle formation. It also should be noted that even in the AN-dominated period we cannot rule out a contribution from open biomass burning to the ZOTTO particles, which would increase the overall particle diameter.

Next, we examine two biomass-burning events in detail, one is the period of 20 April 15:00 LT to 22 April 2008 23:00 LT, and the other is 20 July 15:00 LT to 22 July 2007 23:00 LT. Elevated CO and aerosol absorption were observed during both episodes. We selected these two cases because they were the most prominent events during our study period and represent two different types of biomass-burning events that influence the ZOTTO site. Figure 8a, b gives the footprints of the tower measurements during these periods overlaid with the active fires as observed by the MODIS satellite. It is clear in the April 2008 episode that ZOTTO was under strong influence of large-scale biomass burning in the Kazakh steppe region, which consists of agricultural waste burning. In contrast, during July 2007, forest fires northwest 
Table 4. Median and range for absorption coefficient, $\mathrm{CO}, \mathrm{CH}_{4}$, and total aerosol number concentration from different airmass regions during winter polluted periods.

\begin{tabular}{lrrr}
\hline & South & Southwest & Rest \\
\hline$\sigma_{\mathrm{ap}}\left(574 \mathrm{~nm}, \mathrm{Mm}^{-1}\right)$ & $4.1(0.2-22.5)$ & $3.2(0.1-12.4)$ & $1.5(0.0-10.0)$ \\
$\mathrm{CO}(\mathrm{ppb})$ & $186(142-315)$ & $181(134-246)$ & $172(147-212)$ \\
$\mathrm{CH}(\mathrm{ppb})$ & $1909(1859-2035)$ & $1921(1881-2029)$ & $1954(1889-2035)$ \\
Number $\left(\mathrm{cm}^{-3}\right)$ & $903(190-2964)$ & $914(35-3608)$ & $301(3-2978)$ \\
\hline
\end{tabular}

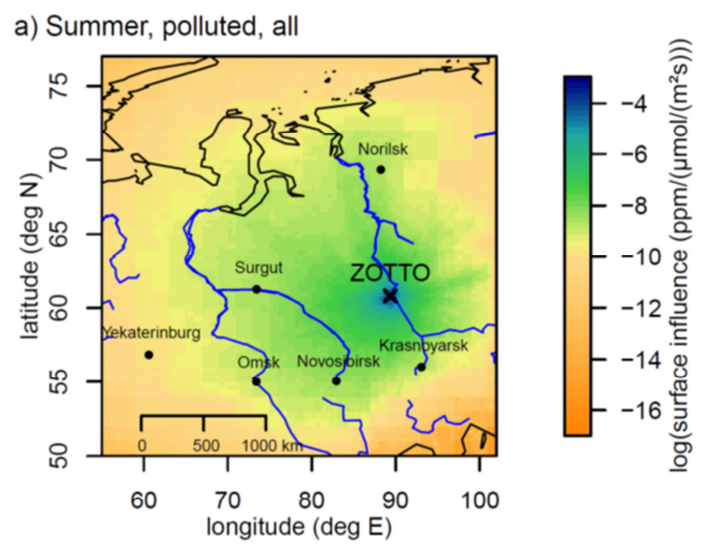

b) Biomass burning dominated

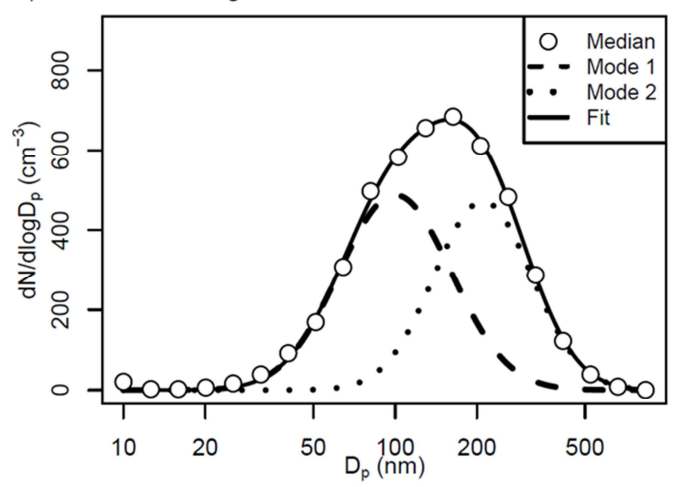

c) Fossil fuel dominated

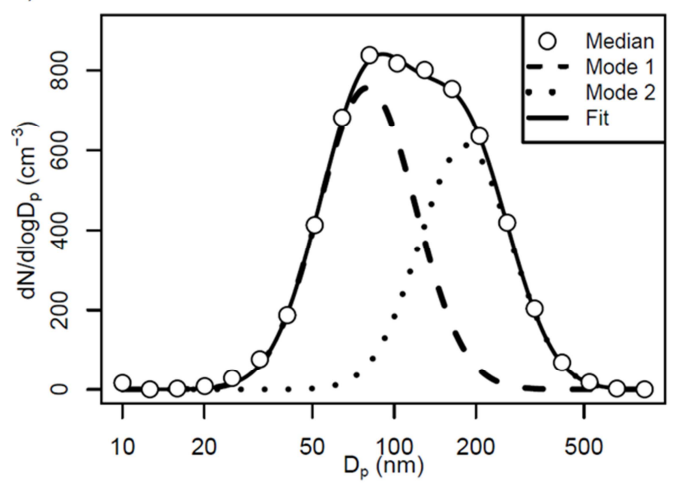

Fig. 7. (a) Footprint of summer polluted periods with the aerosol size distributions for (b) biomass-burning-dominated and (c) fossilfuel-dominated pollution periods. of ZOTTO were the main reason for our elevated concentrations; some of these fires were even very close to our site.

Scatter plots between $\mathrm{CO}$ and $\mathrm{BC}_{\mathrm{e}}$ and $\mathrm{CN}$ and $\mathrm{CO}$ during the April 2008 and July 2007 biomass-burning episodes are shown in Fig. 8e-f. Good correlations between $\mathrm{CO}$ and $\mathrm{BC}_{\mathrm{e}}$ during both episodes suggest one dominant source in each case. The slopes $\left(\Delta \mathrm{BC}_{\mathrm{e}} / \Delta \mathrm{CO}\right.$ ratios) are quite different between the two events and suggest different source characteristics. Our ratio of $10 \mathrm{ng} \mathrm{m}^{-3} \mathrm{ppb}^{-1}$ in July 2007 is already at the high end of literature values for open biomass burning. The ratio in April 2008 is even two times higher than that in July 2007. Higher BC emission ratios for agricultural waste burning than for forest burning have been observed before. Warneke et al. (2009) found a ratio of $10 \mathrm{ng} \mathrm{m}^{-3} \mathrm{ppb}^{-1}$ for Kazakhstan agricultural plumes, and $7 \mathrm{ng} \mathrm{m}^{-3} \mathrm{ppb}^{-1}$ for forest burning around Lake Baikal in April 2008. This is mainly due to higher combustion efficiency in agricultural waste burning than in forest fires. Our ratio of $21.8 \mathrm{ng} \mathrm{m}^{-3} \mathrm{ppb}^{-1}$ for the April 2008 episode is even higher, but a similar event has been observed in a recent study by Cristofanelli et al. (2013). They give a $\Delta \mathrm{BC} / \Delta \mathrm{CO}$ ratio of $29 \mathrm{ng} \mathrm{m}^{-3} \mathrm{ppb}^{-1}$ in an agricultural plume from southern Russia, which confirms the trend to such high emission ratios from this type of fire.

A good correlation was found between $\mathrm{CN}$ and $\mathrm{CO}$ in April 2008 with a $\Delta \mathrm{CN} / \Delta \mathrm{CO}$ slope of $18.0 \mathrm{~cm}^{-3} \mathrm{ppb}^{-1}$, similar to previous results for aged smoke. This confirms that our April episode particles are indeed aged smoke particles, which is also consistent with the particle number size distribution in Fig. 8c that shows a dominant peak around $250 \mathrm{~nm}$. We see a second, less important mode at $100 \mathrm{~nm}$, indicating some influence by anthropogenic pollution. As seen from the footprint (Fig. 8a), the biomass-burning source region overlaps with cities in the southwestern directions. In contrast, the fires in the July 2007 episode are very close to ZOTTO (Fig. 8b). Therefore, the particle size distribution changes quickly with time (Fig. 8d), depending on the wind direction from which the fire plumes reach the site. On 19 July 2007, 10:00 LT the fire is even so close that we see very small particles below $20 \mathrm{~nm}$, which will grow fast to the larger sizes that dominate the other time slices. We will not further examine other biomass-burning events, as this topic has been extensively studied for the ZOTTO station for the summer 2007 and spring 2008 by Vasileva et al. (2011). 

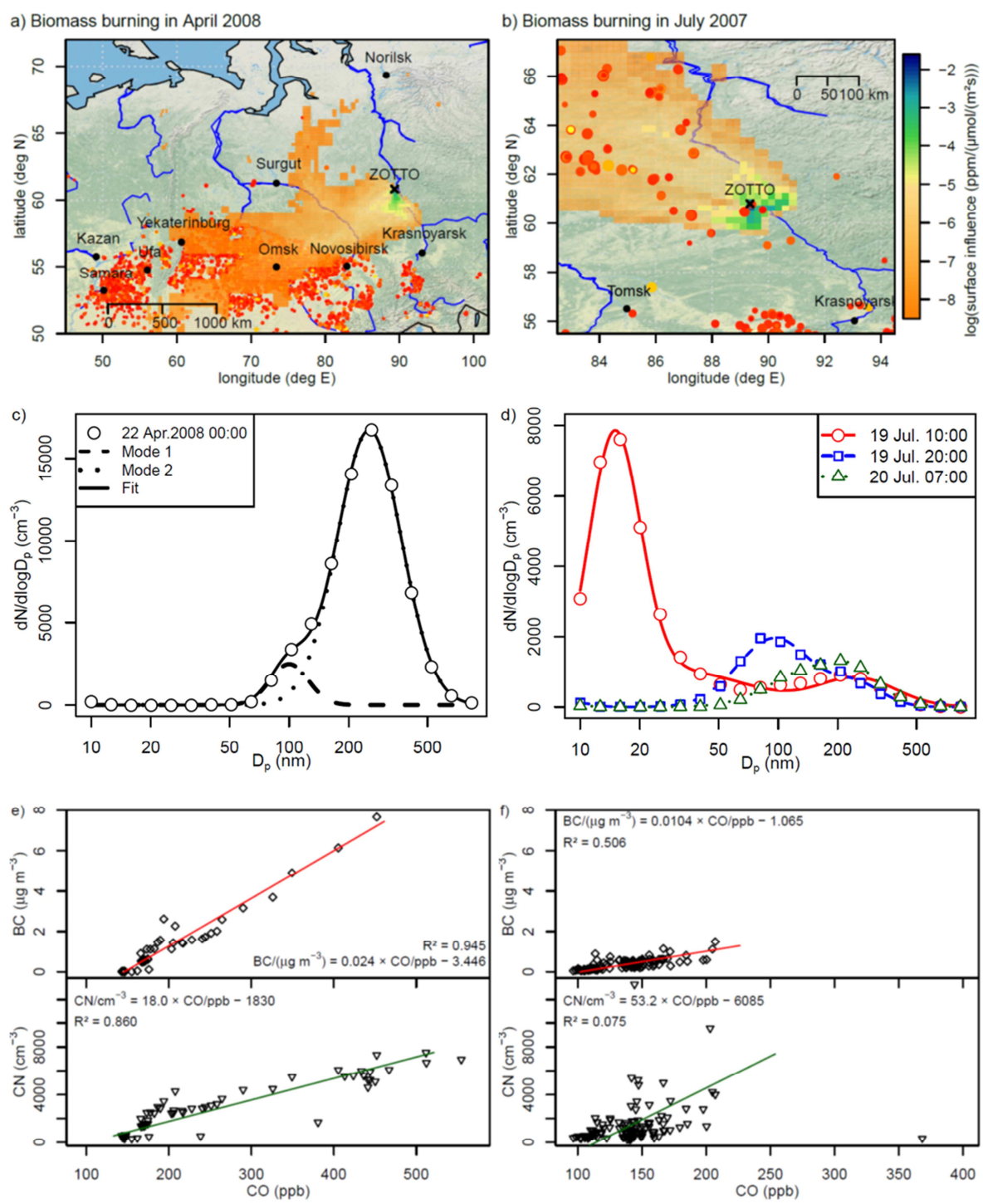

Fig. 8. Footprint overlaid with a fire map, aerosol size distribution, and $\mathrm{BC}_{\mathrm{e}}$ vs. $\mathrm{CO}$ and $\mathrm{CN}$ vs. $\mathrm{CO}$ scatter plots for biomass-burning events in April 2008 and July 2007.

Finally, the size distribution data for 16-18 April 2008 reveal another interesting fact. During a three-day period when the temperatures were well below zero degrees (between $-16^{\circ} \mathrm{C}$ and $-3^{\circ} \mathrm{C}$ ), the wind brought particles to the station that continuously grew to larger size. Figure 9 a gives an overview of the evolution of this process. The particles grew from $40 \mathrm{~nm}$ to $100 \mathrm{~nm}$ within the first $30 \mathrm{~h}$ with a growth rate of about $2 \mathrm{~nm} \mathrm{~h}^{-1}$ (Fig. 9b). This rate is comparable to that at other Siberian remote sites, e.g., at Lake Baikal (Dal Maso et al., 2007), but lower than the $4.5 \mathrm{~nm} \mathrm{~h}^{-1}$ observed at Tomsk (Dal Maso et al., 2007), and higher than the $0.5-0.7 \mathrm{~nm} \mathrm{~h}^{-1}$ at the Finnish station Hyytiälä (Tunved et al., 2006). We assume that both condensation and coagulation contributed to the particle growth in this period. After $30 \mathrm{~h}$, the particle growth rate decreased to $1 \mathrm{~nm} \mathrm{~h}^{-1}$, probably because coag- ulation became less efficient as the particle number concentration decreased, and only condensation contributed to the particle growth. In the end, after $80 \mathrm{~h}$ of growth, the particles had grown to $160 \mathrm{~nm}$, and the whole process started over again. In urban regions and in the biologically active season at sites like Hyytiälä, one normally sees a diurnal cycle in the particle growth, due to a diurnal cycle in the local emission sources and photochemical processes. In our case, the long growth cycle suggests that the initializing fine particles are not present all the time and therefore have their source at greater distances. 


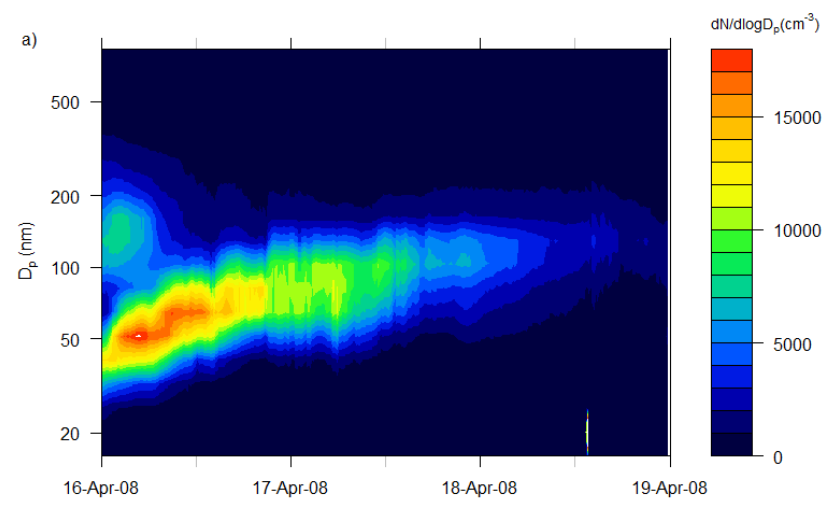

b)

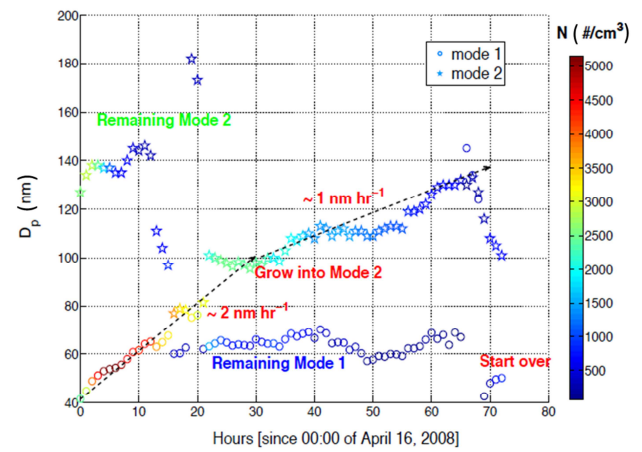

Fig. 9. Particle growth event lasting three days (16-18 April 2008): (a) size distribution as a function of time, (b) growth analysis of dominant size modes.

\subsection{Characterization of pristine air}

Table 3 shows very low concentrations of the combustion related species $\mathrm{CO}$ and $\sigma_{\mathrm{ap}}$ during the pristine periods. The average $\mathrm{CO}$ is even lower than the marine background $\mathrm{CO}$ at the same latitude, which may be related to inflow of air from higher latitudes during clean periods. This confirms that the ZOTTO site is indeed not significantly influenced by regional pollution during our selected pristine periods. The characteristics of pristine air show distinct differences between summer and winter. The $\mathrm{CN}$ and $\mathrm{CCN}$ number concentration, the particle volume concentration, and aerosol scattering coefficient during pristine periods are 2-4 times higher in summer than in winter. In contrast, the winter/summer differences during pollution periods are much smaller. This indicates that the summer peak in our seasonal variation for these parameters is mainly due to natural sources. The Ångström exponent $(\stackrel{a}{a})$ for scattering is also higher (around 2 times) in summer than in winter pristine periods, suggesting particles of smaller size in summer than in winter. Therefore, we will discuss winter and summer separately. In the following subsections, we will first compare our $\mathrm{CN}$ and $\mathrm{CCN}$ concentrations under pristine conditions at ZOTTO with other sites. Then, based on the size distribution data and the footprint,

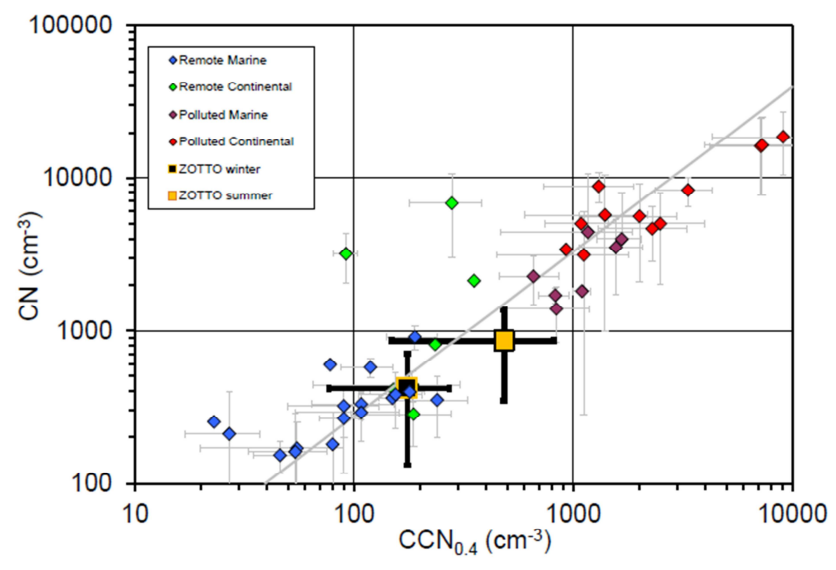

Fig. 10. ZOTTO aerosol number concentrations in global context, based on Andreae (2009).

we characterize winter pristine particles, and in the end we look into the origin of summer particles in pristine air.

\subsection{1 $\mathrm{CN}$ and $\mathrm{CCN}_{0.4}$}

In this study, the $\mathrm{CCN}_{0.4}$ concentration during pristine periods was estimated by the method described in Sect. 2.3.4. The required parameters and results from these calculations are listed in Table 5. In comparison to clean Amazonian particles with a cutoff diameter of about $85 \mathrm{~nm}$ for $\mathrm{CCN}_{0.4}$ (Andreae, 2009), we derived values near $70 \mathrm{~nm}$ for ZOTTO pristine conditions. This is due to a higher $\kappa$ value for ZOTTO than for Amazonian particles. Gunthe et al. (2009) found an average $\kappa$ value of 0.15 in the Amazonian wet season; our summer $\kappa$ value is $60 \%$ higher $(0.24)$, and the winter $\kappa$ value is more than 2 times higher (0.4). This is mainly due to a higher inorganic mass fraction at ZOTTO, particularly in winter. The inorganic mass fraction for Amazonian wet season particles in Gunthe et al. (2009) varied in the range of $5 \%$ to $35 \%$, while at ZOTTO it is $28 \%$ in summer and nearly $60 \%$ in winter (Table 5). A probable explanation is the stronger anthropogenic influence in Siberia than in the Amazon, even during periods classified as "pristine", which suggests that residual pollution still has a significant impact on aerosols in Siberia even during nominally clean periods.

The relationship between the total particle number $\mathrm{CN}$ and $\mathrm{CCN}_{0.4}$ for clean air is shown in Fig. 10 and compared to other stations compiled by Andreae (2009). The $\mathrm{CN}$ numbers at ZOTTO are very similar to those from the Amazon and other pristine regions, while the $\mathrm{CCN}_{0.4}$ numbers are somewhat higher, which can be also seen in the $\mathrm{CCN}_{0.4} / \mathrm{CN}$ ratio in Table 5. As described in the previous paragraph, this might be partly due to the lower critical diameter of $\mathrm{CCN}_{0.4}$ at ZOTTO than in the Amazon, which is related to the chemical composition of the aerosol. In addition, the shape of the particle size distribution strongly influences the $\mathrm{CCN}_{0.4} / \mathrm{CN}$ ratio. For the Amazon, Gunthe et 
Table 5. Organic and inorganic fraction derived from filter samples, calculated hygroscopicity factor, critical diameter for $\mathrm{CCN}_{0.4}, \mathrm{CCN}_{0.4}$ number concentration, and $\mathrm{CCN} / \mathrm{CN}$ ratios for winter and summer pristine air at ZOTTO.

\begin{tabular}{lcccccc}
\hline & $f_{\text {org }}$ & $f_{\text {inorg }}$ & $\kappa$ & $\begin{array}{c}\text { Lower Cutoff } \\
\text { Diameter }\end{array}$ & $\begin{array}{c}N \\
\mathrm{CCN}_{0.4}\end{array}$ & $\mathrm{CCN}_{0.4} / \mathrm{CN}$ \\
\hline Winter & 0.403 & 0.597 & 0.40 & $70 \mathrm{~nm}$ & 193 & 0.56 \\
Summer & 0.713 & 0.287 & 0.24 & $73 \mathrm{~nm}$ & 393 & 0.57 \\
\hline
\end{tabular}

al. (2009) found many particles in the Aitken mode (geometric mean diameter $=57 \mathrm{~nm}$ ). Those particles are not able to act as $\mathrm{CCN}$, because they are smaller than the critical diameter, and only the remaining relatively few particles contribute to the $\mathrm{CCN}_{0.4}$ value (Figs. 3 and 6 in Gunthe et al., 2009). In contrast, the particles in the ZOTTO clean periods are generally larger $\left(D_{\mathrm{g}}\right.$ ranges from $63 \mathrm{~nm}$ to $136 \mathrm{~nm}$, with an overall average at $\sim 80 \mathrm{~nm}$, Fig. 11 ) with a $15 \mathrm{~nm}$ lower cutoff diameter. Therefore, a higher proportion of the $\mathrm{CN}$ contributes to the $\mathrm{CCN}$ at ZOTTO than in the Amazon.

\subsubsection{Clean winter air}

Figure $11 \mathrm{~b}$ shows the median number size distribution of winter aerosol particles for pristine conditions. The absolute concentration of pristine period aerosol particles is much lower than for polluted aerosol particles. The size distribution has a broad mode around $160 \mathrm{~nm}$, which is larger than for polluted particles. When we compare Fig. 11b with Fig. 5f, we can see that pristine period particles have a similar size distribution as polluted particles from the rest region. Moreover, the footprint for the winter clean air (Fig. 11a) also agrees closely to the one for winter polluted air from the rest region (Fig. 5c). It covers large parts of Central Siberia, but excludes all industrial areas, which nicely indicates the consistency between the ZOTTO measurements (pristine values) and the transport model (no industry).

In summary, winter pristine period particles and winter pollution particles from the non-industrialized (rest) region have comparable footprint and size distributions. This leads to the conclusion that the main sources of the observed aerosol particles are the same, comprising both aged particles from anthropogenic sources at great distances from ZOTTO and diluted biofuel burning emissions from heating, and that the different concentrations during clean and polluted periods are mostly due to different degrees of dilution and removal. This and the low values of $\omega_{0}$ during the winter clean periods suggests that even the low $\mathrm{CN}$ and $\mathrm{CCN}$ concentrations present at ZOTTO in winter are dominated by anthropogenic sources and that any natural aerosol concentrations in this region in winter must be extremely low.

\subsubsection{Clean summer air}

The CN number concentration during the summer clean periods is more than three times higher than during winter clean periods (Table 3). Spracklen et al. (2010) summarized $\mathrm{CN}$ concentrations from the free troposphere and continental background sites, and they found a pronounced seasonality at many sites with concentrations being a factor of 2 10 greater in summer than in winter, suggesting new particle formation in summer as the main driver. Since we can exclude significant anthropogenic emissions for the pristine summer conditions based on our tracer criteria, the elevated number concentrations with a very different size distribution than in winter must come from a source other than combustion. Given the atmospheric footprints of clean conditions in Fig. 11c, the formation of new particles followed by growth through condensation of biogenic VOC oxidation products in the boreal forests may account for the elevated particle numbers.

Emissions of VOCs by plants are an important source of SOA precursors; among VOCs, monoterpenes and sesquiterpenes are the most important contributors in temperate and boreal regions (Kanakidou et al., 2005). It has been shown in field and lab experiments that terpene emissions in interaction with $\mathrm{OH}$ and $\mathrm{O}_{3}$ could drive new particle formation (Laaksonen et al., 2008; Hao et al., 2009). Particle formation has to take place near to the VOC sources, because the VOCs have a light-dependent life time of only $1 \mathrm{~min}$ to $3 \mathrm{~h}$ (Kesselmeier and Staudt, 1999).

Once SOA particles have formed, the condensation of VOC oxidation products contributes to particle growth in pristine air, and their size increases with traveling time (Tunved et al., 2006; Riipinen et al., 2012). The meteorological and chemical conditions during transport influence the size distribution (Mäkelä et al., 1997). While our measurement setup does not allow the observation of the nucleation mode below $10 \mathrm{~nm}$, the summer pristine air at ZOTTO is generally dominated by the Aitken mode around $50 \mathrm{~nm}$ (Fig. 11d), in line with previous observations (Mäkelä et al., 1997; Tunved et al., 2006; Dal Maso et al., 2008).

From June to the end of August 2009, an unusual event caused the formation of larger particles than in the summers before (Fig. 11f). This was the only event with such large particles within the whole data set since 2006. The period was characterized by persisting stable weather conditions, 

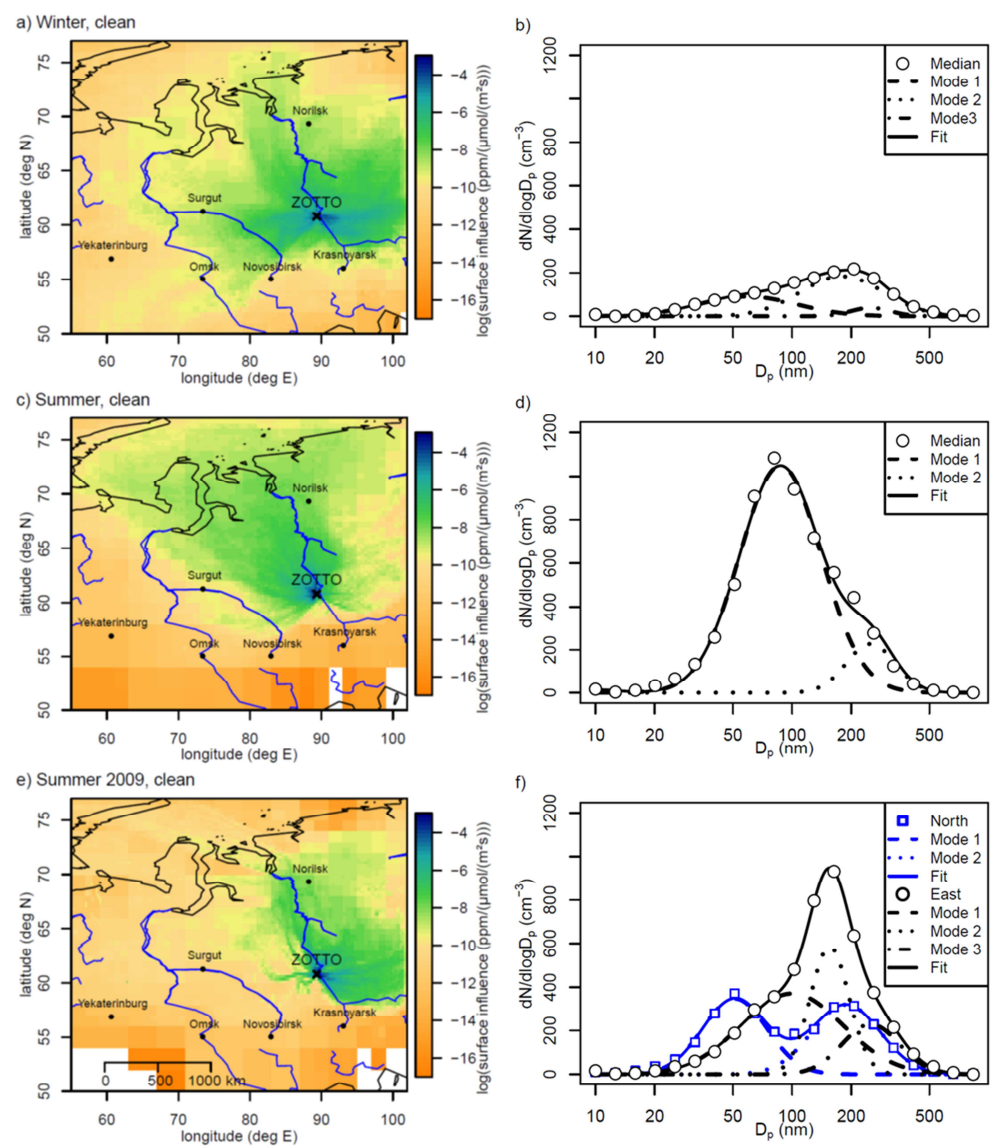

Fig. 11. Footprint and median aerosol number size distribution of clean air periods: (a-b) during winter, (c-d) during summer 2006-2008, (e-f) during summer 2009.

sunshine, warm temperatures, and mostly easterly winds (Fig. 11e). The vegetation in the region east of the Yenisei differs substantially from that on the western side. The eastern region is mountainous and covered by dark taiga (fir, spruce, larch), whereas light taiga with sandy soils and pine forest is dominating in the flat lowlands between the $\mathrm{Ob}$ and Yenisei rivers. However, despite these differences, we could not find a general dependency of the particle size distribution on the wind direction, probably because the different plant species do not emit significantly different VOC amounts (Isidorov et al., 1985; Janson, 1993). However, the biogenic VOC emissions increase exponentially with temperature (Isidorov et al., 1985; Janson, 1993). Accordingly, the ZOTTO data for the pristine summer air reveal a clear temperature dependence (Fig. 12a) with increasing number concentration and particle size for higher air temperatures. The particle volume concentration shows a clear linear increase with temperature (Fig. 12b). An increase of the accumulation mode particle and $\mathrm{CCN}$ number concentrations with temperature has also been observed by Ahlm et al. (2013) and Paasonen et al. (2013). Parts of the temperature dependence originate from the day-night cycle, since the average diurnal cycle of the size distribution in Fig. 13 has a maximum during the warm noon period, which has been observed as well by Dal Maso et al. (2008). The correlation also holds, however, when $24 \mathrm{~h}$ averages are used instead of the $1 \mathrm{~h}$ averages shown in Fig. 12, indicating that the influence of higher temperatures on SOA production extends beyond diurnal effects.

In summary for the clean air period in summer 2009, the particle distribution in ZOTTO was dominated by an elevated size mode at $160-200 \mathrm{~nm}$. The prevailing high temperatures and sunny conditions stimulated VOC emissions and particle growth. This facilitated the growth of the aged particles into the accumulation mode (at 200-250 nm) (Covert and Heintzenberg, 1993; Mäkelä et al., 1997). Given the higher mean radius of those particles, the total particle volume was larger, even with a smaller absolute number concentration. This extraordinary event in 2009 would be a good subject for further modeling studies.

Before these summer conditions, ZOTTO experienced a cold surge from the north in the beginning of June 2009. The footprint in Fig. 11e already indicates an airflow along the Yenisei River from the Norilsk region. During this time, the temperatures fell to $3^{\circ} \mathrm{C}$, biogenic emissions were 

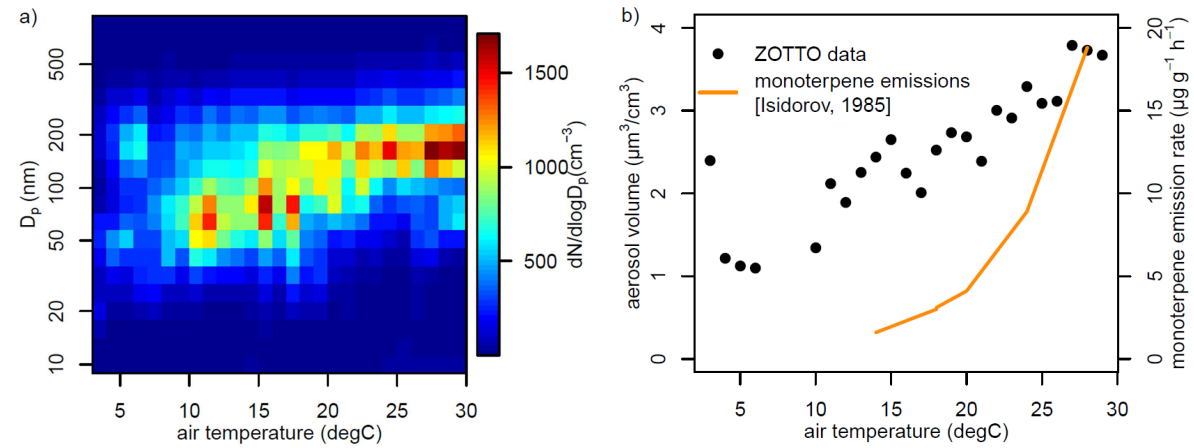

Fig. 12. (a) Color-coded number size distribution depending on air temperature $\left(x\right.$ axis in $\left.{ }^{\circ} \mathrm{C}\right)$; (b) aerosol volume increasing with air temperature; solid line: monoterpene emissions vs. temperature from Scots pine (Isidorov et al., 1985).

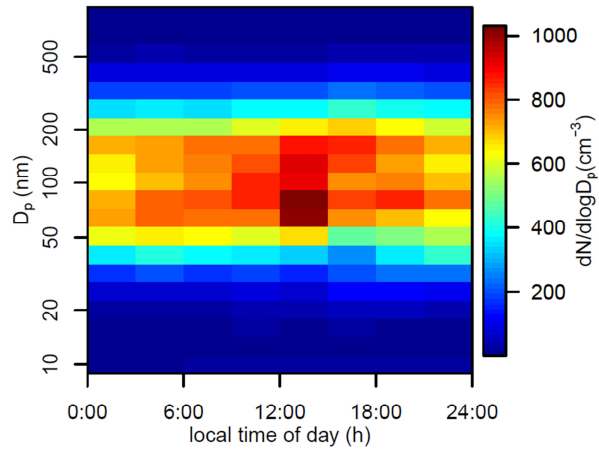

Fig. 13. Diurnal cycle of number size distribution; the color code represents particle number concentrations.

suppressed, and the particle size distribution changed completely, with a sharp reduction of the accumulation mode and the appearance of a mode at $50 \mathrm{~nm}$ (Fig. 11f, north). It is known that nucleation can also happen through activation of sulfate clusters (Kulmala et al., 2004a), which are produced from oxidation of the $\mathrm{SO}_{2}$ emitted in large quantities in Norilsk (Walter et al., 2012). Once more, this event shows the capabilities to trace back aerosol emission sources with the help of the regional transport model and the comprehensive ZOTTO data set.

\section{Summary and conclusions}

We presented the time series of $\mathrm{CO}$ and aerosol measurements at the ZOTTO site for the years 2006 to 2011. First, we introduced the setup to measure aerosol absorption and scattering, black carbon concentration, the particle total number and their size distributions, as well as the $\mathrm{CO}$ concentration. We extracted the seasonal cycle of $\mathrm{CO}$ and compared it to marine background conditions. Due to the remote, very continental location, the station receives episodically very clean air masses. The $\mathrm{CO}$ and aerosol absorption data allowed us a clear separation of pristine from polluted periods, to study their general character.

In winter, when the $\mathrm{CO}$ mixing ratio and aerosol absorption reach their maxima, pollution aerosol particles from anthropogenic emissions are dominant. Within the selected pollution periods, higher $\mathrm{CO}$, aerosol absorption and scattering coefficients, and particle number concentration were found for air masses from southern and southwestern regions, where the major cities and industries are located. The characterization of $\Delta \mathrm{BC}_{\mathrm{e}} / \Delta \mathrm{CO}$ and $\Delta \mathrm{CN} / \Delta \mathrm{CO}$ ratios from these two source regions suggests that the contribution of coal and biofuel burning for heating is higher in these Siberian cities than elsewhere. The aerosol particles from these two regions have a dominant mode around $100 \mathrm{~nm}$. In contrast, polluted particles from the remaining rural regions are much larger (mode at $160 \mathrm{~nm}$ ) with much lower total number concentrations, similar to values observed during winter pristine periods. In conclusion, ZOTTO winter pollution originates mainly from the big cities to the south and southwest of the site, with dominant coal and biofuel contributions. The particles from the rural region during polluted and pristine conditions in winter consist mostly of aged anthropogenic particles from long-range transport and from residential biofuel burning.

During summer, the CO mixing ratios and aerosol absorption coefficients reach their minimum at ZOTTO, which suggests a lower pollution influence. Apart from anthropogenic emissions, large-scale biomass burning is thought to be the main source of pollution particles at ZOTTO in summer. The CO model results from STILT suggest that overall, anthropogenic emissions are the dominant contributor to the pollution particles at ZOTTO, and overall only $12 \%$ of the polluted events are classified as biomass-burning-dominated. However, biomass-burning events are often associated with extremely high $\mathrm{CO}$ concentrations and aerosol absorption coefficients. Two biomass-burning case studies revealed different $\Delta \mathrm{BC}_{\mathrm{e}} / \triangle \mathrm{CO}$ ratios from different fire types, with the agricultural fires in April yielding a very high ratio of $21 \mathrm{ng} \mathrm{m}^{-3} \mathrm{ppb}^{-1}$. The particle number size distributions 
show larger particle sizes from biomass burning than from anthropogenic pollution, which is in line with earlier studies.

In pristine summer air, $\mathrm{CO}$ mixing ratios and aerosol absorption coefficients are low, whereas the total particle number and volume concentrations are comparable to that in summer polluted air, resulting in summer maxima in aerosol scattering and particle volume concentrations. The simultaneous minimum in combustion products and the presence of a particle mode around $60 \mathrm{~nm}$ indicates new particle formation followed by particle growth from biogenic precursors. The summer pristine particles reveal different size modes depending on the environmental conditions. While the summer seasons 2007-2008 were dominated by an Aitken mode at $80 \mathrm{~nm}$, the summer of 2009 with prevailing easterly winds produced particles in the accumulation mode around $200 \mathrm{~nm}$. We found these differences related mainly to air temperature, in parallel with the biogenic VOC production rates. The continuation of the ZOTTO observations will enable the observation of additional events, which will allow studying the reasons for this behavior in detail.

In conclusion, the ZOTTO data set revealed very efficient biomass burning in the steppe regions, and it facilitated the investigation of pristine air composition. In winter, heating with coal and biofuel dominates background aerosol particles; in summer, the boreal VOC emissions control aerosol particle concentrations and properties. Further studies at ZOTTO may investigate the link between aerosol and climate: e.g., increased forest growth by rising temperatures and $\mathrm{CO}_{2}$ stimulated VOC emissions, which feed back on cloud formation (Kulmala et al., 2004b; Arneth et al., 2010; Paasonen et al., 2013). The continuing ZOTTO record will help to detect these trends in natural aerosol emissions and their influences on future climate.

Acknowledgements. The ZOTTO project is funded by the Max Planck Society through the International Science and Technology Center (ISTC) partner project no. 2757 within the framework of the proposal "Observing and Understanding Biogeochemical Responses to Rapid Climate Changes in Eurasia". We thank $\mathrm{N}$. Jürgens for the initial setup of the $\mathrm{CO}$ and aerosol instrumentation. For servicing the ZOTTO station, we acknowledge the work of A. Panov's team from the Sukachev Institute of Forest in Krasnoyarsk, Russia.

The service charges for this open access publication have been covered by the Max Planck Society.

Edited by: V.-M. Kerminen

\section{References}

Aaltonen, V., Lihavainen, H., Kerminen, V.-M., Komppula, M., Hatakka, J., Eneroth, K., Kulmala, M., and Viisanen, Y.: Measurements of optical properties of atmospheric aerosols in Northern Finland, Atmos. Chem. Phys., 6, 1155-1164, doi:10.5194/acp-6-1155-2006, 2006.

Ahlm, L., Shakya, K. M., Russell, L. M., Schroder, J. C., Wong, J. P. S., Sjostedt, S. J., Hayden, K. L., Liggio, J., Wentzell, J. J. B., Wiebe, H. A., Mihele, C., Leaitch, W. R., and Macdonald, A. M.: Temperature-dependent accumulation mode particle and cloud nuclei concentrations from biogenic sources during WACS 2010, Atmos. Chem. Phys., 13, 3393-3407, doi:10.5194/acp-133393-2013, 2013.

Anderson, B. E., Grant, W. B., Gregory, G. L., Browell, E. V., Collins, J. E., Jr., Sachse, G. W., Bagwell, D. R., Hudgins, C. H., Blake, D. R., and Blake, N. J.: Aerosols from biomass burning over the tropical South Atlantic region: Distributions and impacts, J. Geophys. Res., 101, 24117-24138, 1996a.

Anderson, T. L. and Ogren, J. A.: Determining aerosol radiative properties using the TSI 3563 integrating nephelometer, Aerosol Sci. Tech., 29, 57-69, 1998.

Anderson, T. L., Covert, D. S., Marshall, S. F., Laucks, M. L., Charlson, R. J., Waggoner, A. P., Ogren, J. A., Caldow, R., Holm, R. L., Quant, F. R., Sem, G. J., Wiedensohler, A., Ahlquist, N. A., and Bates, T. S.: Performance characteristics of a high-sensitivity, three- wavelength, total scatter/backscatter nephelometer, J. Atmos. Ocean. Tech., 13, 967-986, 1996b.

Anderson, T. L., Covert, D. S., Wheeler, J. D., Harris, J. M., Perry, K. D., Trost, B. E., Jaffe, D. J., and Ogren, J. A.: Aerosol backscatter fraction and single scattering albedo: Measured values and uncertainties at a coastal station in the Pacific Northwest, J. Geophys. Res., 104, 26793-26807, 1999.

Anderson, T. L., Masonis, S. J., Covert, D. S., Ahlquist, N. C., Howell, S. G., Clarke, A. D., and McNaughton, C. S.: Variability of aerosol optical properties derived from in situ aircraft measurements during ACE-Asia, J. Geophys. Res., 108, 8647, doi:10.1029/2002JD003247, 2003.

Andreae, M. O.: Aerosols before pollution, Science, 315, 50-51, 2007.

Andreae, M. O.: Correlation between cloud condensation nuclei concentration and aerosol optical thickness in remote and polluted regions, Atmos. Chem. Phys., 9, 543-556, doi:10.5194/acp-9-543-2009, 2009.

Andreae, M. O. and Gelencsér, A.: Black carbon or brown carbon? The nature of light-absorbing carbonaceous aerosols, Atmos. Chem. Phys., 6, 3131-3148, doi:10.5194/acp-6-3131-2006, 2006.

Andreae, M. O. and Rosenfeld, D.: Aerosol-cloud-precipitation interactions. Part 1. The nature and sources of cloud-active aerosols, Earth-Sci. Rev., 89, 13-41, 2008.

Andreae, M. O., Artaxo, P., Beck, V., Bela, M., Freitas, S., Gerbig, C., Longo, K., Munger, J. W., Wiedemann, K. T., and Wofsy, S. C.: Carbon monoxide and related trace gases and aerosols over the Amazon Basin during the wet and dry seasons, Atmos. Chem. Phys., 12, 6041-6065, doi:10.5194/acp-12-6041-2012, 2012

Arneth, A., Harrison, S. P., Zaehle, S., Tsigaridis, K., Menon, S., Bartlein, P. J., Feichter, J., Korhola, A., Kulmala, M., O’Donnell, D., Schurgers, G., Sorvari, S., and Vesala, T.: Terrestrial biogeochemical feedbacks in the climate system, Nat. Geosci., 3, 525532, doi:10.1038/Ngeo905, 2010.

Birmili, W., Stratmann, F., and Wiedensohler, A.: Design of a DMA-based size spectrometer for a large particle size range and stable operation, J. Aerosol Sci., 30, 549-553, 1999. 
Birmili, W., Wiedensohler, A., Heintzenberg, J., and Lehmann, K.: Atmospheric particle number size distribution in central Europe: Statistical relations to air masses and meteorology, J. Geophys. Res., 106, 32005-32018, 2001.

Birmili, W., Stopfkuchen, K., Hermann, M., Wiedensohler, A., and Heintzenberg, J.: Particle penetration through a $300 \mathrm{~m}$ inlet pipe for sampling atmospheric aerosols from a tall meteorological tower, Aerosol Sci. Tech., 41, 811-817, 2007.

Bond, T. C., Anderson, T. L., and Campbell, D.: Calibration and intercomparison of filter-based measurements of visible light absorption by aerosols, Aerosol Sci. Tech., 30, 582-600, 1999.

Bond, T. C., Covert, D. S., and Müller, T.: Truncation and angularscattering corrections for absorbing aerosol in the TSI 3563 nephelometer, Aerosol Sci. Tech., 43, 866-871, 2009.

Bond, T. C., Doherty, S. J., Fahey, D. W., Forster, P. M., Berntsen, T., DeAngelo, B. J., Flan-ner, M. G., Ghan, S., Kärcher, B., Koch, D., Kinne, S., Kondo, Y., Quinn, P. K., Sarofim, M. C., Schultz, M. G., Schulz, M., Venkataraman, C., Zhang, H., Zhang, S., Bellouin, N., Guttikunda, S. K., Hopke, P. K., Jacobson, M. Z., Kaiser, J. W., Klimont, Z., Lohmann, U., Schwarz, J. P., Shindell, D., Storelvmo, T., Warren, S. G., and Zender, C. S.: Bounding the role of black carbon in the climate system: A scientific assessment, J. Geophys. Res., 118, 1-173, doi:10.1002/jgrd.50171, 2013.

Cabada, J. C., Khlystov, A., Wittig, A. E., Pilinis, C., and Pandis, S. N.: Light scattering by fine particles during the Pittsburgh Air Quality Study: measurements and modeling, J. Geophys. Res., 109, D16S03, doi:10.1029/2003JD004155, 2004.

Cappa, C. D., Lack, D. A., Burkholder, J. B., and Ravishankara, A. R.: Bias in filter-based aerosol light absorption measurements due to organic aerosol loading: Evidence from laboratory measurements, Aerosol Sci. Tech., 42, 1022-1032, 2008.

Chi, X., Mikhailov, E. F., Vasileva, S., Panov, A., and Andreae, M.: Chemical composition, and mass closure of Siberia aerosols at ZOTTO, Russia, April 2010 to May 2012, in preparation, 2013.

Chung, C. E., Ramanathan, V., and Decremer, D.: Observationally constrained estimates of carbonaceous aerosol radiative forcing, P. Natl. Acad. Sci. USA, 109, 11624-11629, doi:10.1073/pnas.1203707109, 2012.

Conard, S. G. and Ivanova, G. A.: Wildfire in Russian boreal forests - Potential impacts of fire regime characteristics on emissions and global carbon balance estimates, Environ. Pollut., 98, 305313, 1997.

Covert, D. S. and Heintzenberg, J.: Size Distributions and Chemical-Properties of Aerosol at Ny Alesund, Svalbard, Atmos. Environ., 27, 2989-2997, 1993.

Cristofanelli, P., Fierli, F., Marinoni, A., Calzolari, F., Duchi, R., Burkhart, J., Stohl, A., Maione, M., Arduini, J., and Bonasoni, P.: Influence of biomass burning and anthropogenic emissions on ozone, carbon monoxide and black carbon at the Mt. Cimone GAW-WMO global station (Italy, 2165 m a.s.l.), Atmos. Chem. Phys., 13, 15-30, doi:10.5194/acp-13-15-2013, 2013.

Crosson, E. R.: A cavity ringdown analyzer for measuring atmospheric levels of methane, carbon dioxide, and water vapor, Appl. Phys. B., 92, 403-408, doi:10.1007/s00340-008-3135-y, 2008.

Dal Maso, M., Sogacheva, L., Vlasov, A., Staroverova, A., Lushnikov, A., Anisimov, M., Zagaynov, V. A., Khodzher, T. V., Obolkin, V. A., Lyubotseva, Y. S., Riipinen, I., Kerminen, V. M., and Kulmala, M.: Aerosol particle formation events at two
Siberian stations, in: Nucleation and Atmospheric Aerosols, edited by: O'Dowd, C. D. and Wagner, P. E., Springer, 840-844, 2007.

Dal Maso, M., Sogacheva, L., Anisimov, M. P., Arshinov, M., Baklanov, A., Belan, B., Khodzher, T. V., Obolkin, V. A., Staroverova, A., Vlasov, A., Zagaynov, V. A., Lushnikov, A., Lyubovtseva, Y. S., Riipinen, I., Kerminen, V. M., and Kulmala, M.: Aerosol particle formation events at two Siberian stations inside the boreal forest, Boreal Environ. Res., 13, 81-92, 2008.

Daniel, J. S. and Solomon, S.: On the climate forcing of carbon monoxide, J. Geophys. Res., 103, 13249-13260, 1998.

Delene, D. J. and Ogren, J. A.: Variability of aerosol optical properties at four North American surface monitoring sites, J. Atmos. Sci., 59, 1135-1150, 2002.

Dubovik, O., Holben, B., Eck, T. F., Smirnov, A., Kaufman, Y. J., King, M. D., Tanre, D., and Slutsker, I.: Variability of absorption and optical properties of key aerosol types observed in worldwide locations, J. Atmos. Sci., 59, 590-608, 2002.

Duncan, B. N. and Logan, J. A.: Model analysis of the factors regulating the trends and variability of carbon monoxide between 1988 and 1997, Atmos. Chem. Phys., 8, 7389-7403, doi:10.5194/acp-8-7389-2008, 2008.

Duncan, B. N., Logan, J. A., Bey, I., Megretskaia, I. A., Yantosca, R. M., Novelli, P. C., Jones, N. B., and Rinsland, C. P.: Global budget of CO, 1988-1997: Source estimates and validation with a global model, J. Geophys. Res., 112, D22301, doi:10.1029/2007jd008459, 2007.

Dusek, U., Frank, G. P., Hildebrandt, L., Curtius, J., Schneider, J., Walter, S., Chand, D., Drewnick, F., Hings, S., Jung, D., Borrmann, S., and Andreae, M. O.: Size matters more than chemistry for cloud nucleating ability of aerosol particles, Science, 312, 1375-1378, 2006.

EDGAR-4.1: European Commission, Joint Research Centre (JRC)/Netherlands Environmental Assessment Agency (PBL). Emission Database for Global Atmospheric Research (EDGAR), release version 4.1. http://edgar.jrc.ec.europa.eu, 2010.

Fiebig, M., Stohl, A., Wendisch, M., Eckhardt, S., and Petzold, A.: Dependence of solar radiative forcing of forest fire aerosol on ageing and state of mixture, Atmos. Chem. Phys., 3, 881-891, doi:10.5194/acp-3-881-2003, 2003.

Fisher, J. A., Jacob, D. J., Purdy, M. T., Kopacz, M., Le Sager, P., Carouge, C., Holmes, C. D., Yantosca, R. M., Batchelor, R. L., Strong, K., Diskin, G. S., Fuelberg, H. E., Holloway, J. S., Hyer, E. J., McMillan, W. W., Warner, J., Streets, D. G., Zhang, Q., Wang, Y., and Wu, S.: Source attribution and interannual variability of Arctic pollution in spring constrained by aircraft (ARCTAS, ARCPAC) and satellite (AIRS) observations of carbon monoxide, Atmos. Chem. Phys., 10, 977-996, doi:10.5194/acp10-977-2010, 2010.

Fujitani, Y., Murao, N., Ohta, S., Endoh, T., and Yamagata, S.: Optical and chemical properties of marine aerosols over the central equatorial Pacific Ocean during the 2003 R/V Mirai cruise, J. Geophys. Res., 112, D11213, doi:10.1029/2006JD008354, 2007.

Garland, R. M., Yang, H., Schmid, O., Rose, D., Nowak, A., Achtert, P., Wiedensohler, A., Takegawa, N., Kita, K., Miyazaki, Y., Kondo, Y., Hu, M., Shao, M., Zeng, L. M., Zhang, Y. H., Andreae, M. O., and Pöschl, U.: Aerosol optical properties in a rural environment near the mega-city Guangzhou, China: implications for regional air pollution, radiative forcing and remote 
sensing, Atmos. Chem. Phys., 8, 5161-5186, doi:10.5194/acp-85161-2008, 2008.

Garland, R. M., Schmid, O., Gunthe, S. S., Nowak, A., Wiedensohler, A., Takegawa, N., Kita, K., Kondo, Y., Hu, M., Shao, M., Zeng, L., Zhu, T., Andreae, M. O., and Pöschl, U.: Aerosol optical properties observed during CAREBeijing-2006: Characteristic differences between the inflow and outflow of Beijing city air, J. Geophys. Res., 114, D00G04, doi:10.1029/2008JD010780, 2009.

Gebhart, K. A., Copeland, S., and Malm, W. C.: Diurnal and seasonal patterns in light scattering, extinction, and relative humidity, Atmos. Environ., 35, 5177-5191, 2001.

Gelencsér, A.: Carbonaceous aerosol, Springer, Dordrecht, Netherlands, 350 pp., 2004

Gerbig, C., Lin, J. C., Wofsy, S. C., Daube, B. C., Andrews, A. E., Stephens, B. B., Bakwin, P. S., and Grainger, C. A.: Toward constraining regional-scale fluxes of $\mathrm{CO}_{2}$ with atmospheric observations over a continent: 2. Analysis of COBRA data using a receptor-oriented framework, J. Geophys. Res., 108, 4757, doi:10.1029/2003jd003770, 2003.

GLOBALVIEW-CO: GLOBALVIEW-CO: Cooperative Atmospheric Data Integration Project - Carbon Monoxide. CDROM, NOAA ESRL, Boulder, Colorado [Also available on Internet via anonymous FTP to ftp://cmdl.noaa.gov, Path: ccg/co/GLOBALVIEW] (last access: 24 March 2012), 2009.

Gloor, M., Bakwin, P., Hurst, D., Lock, L., Draxler, R., and Tans, P.: What is the concentration footprint of a tall tower?, J. Geophys. Res., 106, 17831-17840, 2001.

Gunthe, S. S., King, S. M., Rose, D., Chen, Q., Roldin, P., Farmer, D. K., Jimenez, J. L., Artaxo, P., Andreae, M. O., Martin, S. T., and Pöschl, U.: Cloud condensation nuclei in pristine tropical rainforest air of Amazonia: size-resolved measurements and modeling of atmospheric aerosol composition and CCN activity, Atmos. Chem. Phys., 9, 7551-7575, doi:10.5194/acp-9-75512009, 2009.

Guyon, P., Graham, B., Roberts, G. C., Mayol-Bracero, O. L., Maenhaut, W., Artaxo, P., and Andreae, M. O.: In-canopy gradients, composition, sources, and optical properties of aerosol over the Amazon forest, J. Geophys. Res., 108, 4591, doi:10.1029/2003JD003465, 2003.

Guyon, P., Graham, B., Roberts, G. C., Mayol-Bracero, O. L., Maenhaut, W., Artaxo, P., and Andreae, M. O.: Sources of optically active aerosol particles over the Amazon forest, Atmos. Environ., 38, 1039-1051, 2004.

Guyon, P., Frank, G. P., Welling, M., Chand, D., Artaxo, P., Rizzo, L., Nishioka, G., Kolle, O., Fritsch, H., Silva Dias, M. A. F, Gatti, L. V., Cordova, A. M., and Andreae, M. O.: Airborne measurements of trace gas and aerosol particle emissions from biomass burning in Amazonia, Atmos. Chem. Phys., 5, 2989 3002, doi:10.5194/acp-5-2989-2005, 2005.

Hansen, J., Sato, M., Lacis, A., and Ruedy, R.: The missing climate forcing, Philos. T. Roy. Soc. B, 352, 231-240, 1997.

Hao, L. Q., Yli-Pirilä, P., Tiitta, P., Romakkaniemi, S., Vaattovaara, P., Kajos, M. K., Rinne, J., Heijari, J., Kortelainen, A., Miettinen, P., Kroll, J. H., Holopainen, J. K., Smith, J. N., Joutsensaari, J., Kulmala, M., Worsnop, D. R., and Laaksonen, A.: New particle formation from the oxidation of direct emissions of pine seedlings, Atmos. Chem. Phys., 9, 8121-8137, doi:10.5194/acp9-8121-2009, 2009.
Hedberg, E., Kristensson, A., Ohlsson, M., Johansson, C., Johansson, P. A., Swietlicki, E., Vesely, V., Wideqvist, U., and Westerholm, R.: Chemical and physical characterization of emissions from birch wood combustion in a wood stove, Atmos. Environ., 36, 4823-4837, doi:10.1016/S1352-2310(02)00417-X, 2002.

Heintzenberg, J. and Birmili, W.: Aerosols over the Siberian Forest: The ZOTTO project, Journal of the Cryogenic Society of Japan, $68,1-4,2010$.

Heintzenberg, J., Birmili, W., Theiss, D., and Kisilyakhov, Y.: The atmospheric aerosol over Siberia, as seen from the $300 \mathrm{~m}$ ZOTTO tower, Tellus B, 60, 276-285, 2008.

Heintzenberg, J., Birmili, W., Otto, R., Andreae, M. O., Mayer, J.C., Chi, X., and Panov, A.: Aerosol particle number size distributions and particulate light absorption at the ZOTTO tall tower (Siberia), 2006-2009, Atmos. Chem. Phys., 11, 87038719, doi:10.5194/acp-11-8703-2011, 2011.

Houghton, J. T., Ding, Y., Griggs, D. J., Noguer, M., van der Linden, P. J., Dai, X., Maskell, K., and Johnson, C. A.: Climate Change 2001: The Scientific Basis. Contribution of Working Group I to the Third Assessment Report of the Intergovernmental Panel on Climate Change, Cambridge University Press, Cambridge, UK, and New York, NY, USA, 881 pp., 2001.

Hsu, Y. K., VanCuren, T., Park, S., Jakober, C., Herner, J., FitzGibbon, M., Blake, D. R., and Parrish, D. D.: Methane emissions inventory verification in southern California, Atmos. Environ., 44, 1-7, 2010.

Hyvarinen, A. P., Kolmonen, P., Kerminen, V. M., Virkkula, A., Leskinen, A., Komppula, M., Hatakka, J., Burkhart, J., Stohl, A., Aalto, P., Kulmala, M., Lehtinen, K. E. J., Viisanen, Y., and Lihavainen, H.: Aerosol black carbon at five background measurement sites over Finland, a gateway to the Arctic, Atmos. Environ., 45, 4042-4050, 2011.

Isidorov, V. A., Zenkevich, I. G., and Ioffe, B. V.: Volatile organic compounds in the atmosphere of forests, Atmos. Environ., 19, $1-8,1985$.

Jaffe, D., Yurganov, L., Pullman, E., Reuter, J., Mahura, A., and Novelli, P.: Measurements of CO and O-3 at Shemya, Alaska, J. Geophys. Res., 103, 1493-1502, 1998.

Janhäll, S., Andreae, M. O., and Pöschl, U.: Biomass burning aerosol emissions from vegetation fires: particle number and mass emission factors and size distributions, Atmos. Chem. Phys., 10, 1427-1439, doi:10.5194/acp-10-1427-2010, 2010.

Janson, R. W.: Monoterpene Emissions from Scots Pine and Norwegian Spruce, J. Geophys. Res., 98, 2839-2850, doi:10.1029/92jd02394, 1993.

Kaiser, J. W., Heil, A., Andreae, M. O., Benedetti, A., Chubarova, N., Jones, L., Morcrette, J.-J., Razinger, M., Schultz, M. G., Suttie, M., and van der Werf, G. R.: Biomass burning emissions estimated with a global fire assimilation system based on observed fire radiative power, Biogeosciences, 9, 527-554, doi:10.5194/bg-9-527-2012, 2012.

Kanakidou, M., Seinfeld, J. H., Pandis, S. N., Barnes, I., Dentener, F. J., Facchini, M. C., Van Dingenen, R., Ervens, B., Nenes, A., Nielsen, C. J., Swietlicki, E., Putaud, J. P., Balkanski, Y., Fuzzi, S., Horth, J., Moortgat, G. K., Winterhalter, R., Myhre, C. E. L., Tsigaridis, K., Vignati, E., Stephanou, E. G., and Wilson, J.: Organic aerosol and global climate modelling: a review, Atmos. Chem. Phys., 5, 1053-1123, doi:10.5194/acp-5-1053-2005, 2005. 
Kasischke, E. S., Hyer, E. J., Novelli, P. C., Bruhwiler, L. P., French, N. H. F., Sukhinin, A. I., Hewson, J. H., and Stocks, B. J.: Influences of boreal fire emissions on Northern Hemisphere atmospheric carbon and carbon monoxide, Global Biogeochem. Сy., 19, GB1012, doi:10.1029/2004GB002300, 2005.

Kesselmeier, J. and Staudt, M.: Biogenic volatile organic compounds (VOC): An overview on emission, physiology and ecology, J. Atmos. Chem., 33, 23-88, 1999.

Kirchstetter, T. W., Novakov, T., and Hobbs, P. V.: Evidence that the spectral dependence of light absorption by aerosols is affected by organic carbon, J. Geophys. Res., 109, D21208, doi:10.1029/2004JD004999, 2004.

Knutson, E. O. and Whitby, K. T.: Anomalous Unipolar Diffusion Charging of Polystyrene Latex Aerosols, J. Colloid Interf. Sci., 53, 493-495, 1975.

Kondo, Y., Komazaki, Y., Miyazaki, Y., Moteki, N., Takegawa, N., Kodama, D., Deguchi, S., Nogami, M., Fukuda, M., Miyakawa, T., Morino, Y., Koike, M., Sakurai, H., and Ehara, K.: Temporal variations of elemental carbon in Tokyo, J. Geophys. Res., 111, D12205, doi:10.1029/2005JD006257, 2006.

Kondo, Y., Matsui, H., Moteki, N., Sahu, L., Takegawa, N., Kajino, M., Zhao, Y., Cubison, M. J., Jimenez, J. L., Vay, S., Diskin, G. S., Anderson, B., Wisthaler, A., Mikoviny, T., Fuelberg, H. E., Blake, D. R., Huey, G., Weinheimer, A. J., Knapp, D. J., and Brune, W. H.: Emissions of black carbon, organic, and inorganic aerosols from biomass burning in North America and Asia in 2008, J. Geophys. Res., 116, D08204, doi:10.1029/2010JD015152, 2011.

Kopacz, M., Jacob, D. J., Fisher, J. A., Logan, J. A., Zhang, L., Megretskaia, I. A., Yantosca, R. M., Singh, K., Henze, D. K., Burrows, J. P., Buchwitz, M., Khlystova, I., McMillan, W. W., Gille, J. C., Edwards, D. P., Eldering, A., Thouret, V., and Nedelec, P.: Global estimates of $\mathrm{CO}$ sources with high resolution by adjoint inversion of multiple satellite datasets (MOPITT, AIRS, SCIAMACHY, TES), Atmos. Chem. Phys., 10, 855-876, doi:10.5194/acp-10-855-2010, 2010.

Koutsenogii, P. K. and Jaenicke, R.: Number concentration and size distribution of atmospheric aerosol in Siberia, J. Aerosol Sci., 25, 377-383, 1994.

Kozlova, E. A., Manning, A. C., Kisilyakhov, Y., Seifert, T., and Heimann, M.: Seasonal, synoptic and diurnal-scale variability of biogeochemical trace gas and $\mathrm{O}_{2}$ from a $300 \mathrm{~m}$ tall tower in central Siberia, Global Biogeochem. Cy., 22, GB4020, doi:1029/2008GB003209, 2008.

Kreidenweis, S. M., Petters, M. D., and DeMott, P. J.: Singleparameter estimates of aerosol water content, Environ. Res. Lett., 3, 035002, doi:10.1088/1748-9326/3/3/035002, 2008.

Kreidenweis, S. M., Petters, M. D., and Chuang, P. Y.: Cloud particle precursors, Clouds in the Perturbed Climate System: Their Relationship to Energy Balance, Atmospheric Dynamics, and Precipitation, in: Strüngmann Forum Report, edited by: Heintzenberg, J. and Charlson, R. J., The MIT Press, Cambridge, MA, 2009.

Kuhn, U., Ganzeveld, L., Thielmann, A., Dindorf, T., Schebeske, G., Welling, M., Sciare, J., Roberts, G., Meixner, F. X., Kesselmeier, J., Lelieveld, J., Kolle, O., Ciccioli, P., Lloyd, J., Trentmann, J., Artaxo, P., and Andreae, M. O.: Impact of Manaus City on the Amazon Green Ocean atmosphere: ozone production, precursor sensitivity and aerosol load, Atmos. Chem. Phys., 10, 9251-9282, doi:10.5194/acp-10-9251-2010, 2010.

Kulmala, M., Kerminen, V. M., Anttila, T., Laaksonen, A., and O'Dowd, C. D.: Organic aerosol formation via sulphate cluster activation, J. Geophys. Res., 109, D04205, doi:10.1029/2003JD003961, 2004a.

Kulmala, M., Suni, T., Lehtinen, K. E. J., Dal Maso, M., Boy, M., Reissell, A., Rannik, Ü., Aalto, P., Keronen, P., Hakola, H., Bäck, J., Hoffmann, T., Vesala, T., and Hari, P.: A new feedback mechanism linking forests, aerosols, and climate, Atmos. Chem. Phys., 4, 557-562, doi:10.5194/acp-4-557-2004, 2004b.

Laaksonen, A., Kulmala, M., O’Dowd, C. D., Joutsensaari, J., Vaattovaara, P., Mikkonen, S., Lehtinen, K. E. J., Sogacheva, L., Dal Maso, M., Aalto, P., Petäjä, T., Sogachev, A., Yoon, Y. J., Lihavainen, H., Nilsson, D., Facchini, M. C., Cavalli, F., Fuzzi, S., Hoffmann, T., Arnold, F., Hanke, M., Sellegri, K., Umann, B., Junkermann, W., Coe, H., Allan, J. D., Alfarra, M. R., Worsnop, D. R., Riekkola, M.-L., Hyötyläinen, T., and Viisanen, Y.: The role of VOC oxidation products in continental new particle formation, Atmos. Chem. Phys., 8, 2657-2665, doi:10.5194/acp-82657-2008, 2008.

Lack, D. A., Cappa, C. D., Covert, D. S., Baynard, T., Massoli, P., Sierau, B., Bates, T. S., Quinn, P. K., Lovejoy, E. R., and Ravishankara, A. R.: Bias in filter-based aerosol light absorption measurements due to organic aerosol loading: Evidence from ambient measurements, Aerosol Sci. Tech., 42, 1033-1041, 2008.

Lack, D. A., Langridge, J. M., Bahreini, R., Cappa, C. D., Middlebrook, A. M., and Schwarz, J. P.: Brown carbon and internal mixing in biomass burning particles, P. Natl. Acad. Sci. USA., 109, 14802-14807, 2012.

Lawrence, M. G., Rasch, P. J., von Kuhlmann, R., Williams, J., Fischer, H., de Reus, M., Lelieveld, J., Crutzen, P. J., Schultz, M., Stier, P., Huntrieser, H., Heland, J., Stohl, A., Forster, C., Elbern, H., Jakobs, H., and Dickerson, R. R.: Global chemical weather forecasts for field campaign planning: predictions and observations of large-scale features during MINOS, CONTRACE, and INDOEX, Atmos. Chem. Phys., 3, 267-289, doi:10.5194/acp-3267-2003, 2003.

Lavric, J. V., Heimann, M., Gerbig, C., Winderlich, J., Schulze, E.D., Andreae, M. O., Onuchin, A. A., and Panov, A. V.: Walk Tall: A Look up at the Zotino Tall Tower Observatory, Meteorol. Technol. Intl., September 2011, 6-10, 2011.

Lin, J. C., Gerbig, C., Wofsy, S. C., Andrews, A. E., Daube, B. C., Davis, K. J., and Grainger, C. A.: A near-field tool for simulating the upstream influence of atmospheric observations: The Stochastic Time-Inverted Lagrangian Transport (STILT) model, J. Geophys. Res., 108, 4493, doi:10.1029/2002jd003161, 2003.

Mäkelä, J. M., Aalto, P., Jokinen, V., Pohja, T., Nissinen, A., Palmroth, S., Markkanen, T., Seitsonen, K., Lihavainen, H., and Kulmala, M.: Observations of ultrafine aerosol particle formation and growth in boreal forest, Geophys. Res. Lett., 24, 1219-1222, 1997.

MATCH-MPIC: Model of Atmospheric Transport and Chemistry - Max Planck Institute for Chemistry version, http:// cwf.iass-potsdam.de/match/match_overview.html (last access: 2 April 2012), 2012.

Mogo, S., Cachorro, V. E., Lopez, J. F., Montilla, E., Torres, B., Rodríguez, E., Bennouna, Y., and de Frutos, A. M.: In situ measurements of aerosol optical properties and number size distributions 
in a coastal region of Norway during the summer of 2008, Atmos. Chem. Phys., 12, 5841-5857, doi:10.5194/acp-12-58412012, 2012.

Müller, D., Mattis, I., Wandinger, U., Ansmann, A., Althausen, D., and Stohl, A.: Raman lidar observations of aged Siberian and Canadian forest fire smoke in the free troposphere over Germany in 2003: Microphysical particle characterization, J. Geophys. Res., 110, D17201, doi:10.1029/2004JD005756, 2005.

Nam, E. K., Jensen, T. E., and Wallington, T. J.: Methane emissions from vehicles, Environ. Sci. Technol., 38, 2005-2010, doi:10.1021/Es034837g, 2004.

Nguyen, T. B., Lee, P. B., Updyke, K. M., Bones, D. L., Laskin, J., Laskin, A., and Nizkorodov, S. A.: Formation of nitrogenand sulfur-containing light-absorbing compounds accelerated by evaporation of water from secondary organic aerosols, J. Geophys. Res., 117, D01207, doi:10.1029/2011JD016944, 2012.

Nicks, D. K., Holloway, J. S., Ryerson, T. B., Dissly, R. W., Parrish, D. D., Frost, G. J., Trainer, M., Donnelly, S. G., Schauffler, S., Atlas, E. L., Hubler, G., Sueper, D. T., and Fehsenfeld, F. C.: Fossil-fueled power plants as a source of atmospheric carbon monoxide, J. Environ. Monitor., 5, 35-39, 2003.

Novelli, P. C., Masarie, K. A., and Lang, P. M.: Distributions and recent changes of carbon monoxide in the lower troposphere, J. Geophys. Res., 103, 19015-19033, 1998.

Paasonen, P., Asmi, A., Petaja, T., Kajos, M. K., Aijala, M., Junninen, H., Holst, T., Abbatt, J. P. D., Arneth, A., Birmili, W., van der Gon, H. D., Hamed, A., Hoffer, A., Laakso, L., Laaksonen, A., Leaitch, W. R., Plass-Dulmer, C., Pryor, S. C., Raisanen, P., Swietlicki, E., Wiedensohler, A., Worsnop, D. R., Kerminen, V. M., and Kulmala, M.: Warming-induced increase in aerosol number concentration likely to moderate climate change, Nat. Geosci., 6, 438-442, doi:10.1038/Ngeo1800, 2013.

Petters, M. D. and Kreidenweis, S. M.: A single parameter representation of hygroscopic growth and cloud condensation nucleus activity, Atmos. Chem. Phys., 7, 1961-1971, doi:10.5194/acp-71961-2007, 2007.

Pochanart, P., Akimoto, H., Kajii, Y., Potemkin, V. M., and Khodzher, T. V.: Regional background ozone and carbon monoxide variations in remote Siberia/East Asia, J. Geophys. Res., 108, 4028, doi:10.1029/2001jd001412, 2003.

Putaud, J. P., Raes, F., Van Dingenen, R., Bruggemann, E., Facchini, M. C., Decesari, S., Fuzzi, S., Gehrig, R., Huglin, C., Laj, P., Lorbeer, G., Maenhaut, W., Mihalopoulos, N., Mulller, K., Querol, X., Rodriguez, S., Schneider, J., Spindler, G., ten Brink, H., Torseth, K., and Wiedensohler, A.: European aerosol phenomenology - 2: chemical characteristics of particulate matter at kerbside, urban, rural and background sites in Europe, Atmos. Environ., 38, 2579-2595, 2004.

Reid, J. S. and Hobbs, P. V.: Physical and optical properties of young smoke from individual biomass fires in Brazil, J. Geophys. Res., 103, 32013-32030, 1998.

Reid, J. S., Hobbs, P. V., Ferek, R. J., Blake, D. R., Martins, J. V., Dunlap, M. R., and Liousse, C.: Physical, chemical, and optical properties of regional hazes dominated by smoke in Brazil, J. Geophys. Res., 103, 32059-32080, 1998.

Riipinen, I., Yli-Juuti, T., Pierce, J. R., Petaja, T., Worsnop, D. R., Kulmala, M., and Donahue, N. M.: The contribution of organics to atmospheric nanoparticle growth, Nat. Geosci., 5, 453-458, doi:10.1038/ngeo1499, 2012.
Rose, D., Nowak, A., Achtert, P., Wiedensohler, A., Hu, M., Shao, M., Zhang, Y., Andreae, M. O., and Pöschl, U.: Cloud condensation nuclei in polluted air and biomass burning smoke near the mega-city Guangzhou, China - Part 1: Size-resolved measurements and implications for the modeling of aerosol particle hygroscopicity and CCN activity, Atmos. Chem. Phys., 10, 33653383, doi:10.5194/acp-10-3365-2010, 2010.

Ruckstuhl, A. F., Henne, S., Reimann, S., Steinbacher, M., Vollmer, M. K., O’Doherty, S., Buchmann, B., and Hueglin, C.: Robust extraction of baseline signal of atmospheric trace species using local regression, Atmos. Meas. Tech., 5, 2613-2624, doi:10.5194/amt-5-2613-2012, 2012.

Russell, P. B., Bergstrom, R. W., Shinozuka, Y., Clarke, A. D., DeCarlo, P. F., Jimenez, J. L., Livingston, J. M., Redemann, J., Dubovik, O., and Strawa, A.: Absorption Angstrom Exponent in AERONET and related data as an indicator of aerosol composition, Atmos. Chem. Phys., 10, 1155-1169, doi:10.5194/acp-101155-2010, 2010.

Seinfeld, J. H. and Pandis, S. N.: Atmospheric chemistry and physics: From air pollution to climate change, John Wiley, New York, 1326 pp., 1998.

Spracklen, D. V., Carslaw, K. S., Merikanto, J., Mann, G. W., Reddington, C. L., Pickering, S., Ogren, J. A., Andrews, E., Baltensperger, U., Weingartner, E., Boy, M., Kulmala, M., Laakso, L., Lihavainen, H., Kivekäs, N., Komppula, M., Mihalopoulos, N., Kouvarakis, G., Jennings, S. G., O’Dowd, C., Birmili, W., Wiedensohler, A., Weller, R., Gras, J., Laj, P., Sellegri, K., Bonn, B., Krejci, R., Laaksonen, A., Hamed, A., Minikin, A., Harrison, R. M., Talbot, R., and Sun, J.: Explaining global surface aerosol number concentrations in terms of primary emissions and particle formation, Atmos. Chem. Phys., 10, 4775-4793, doi:10.5194/acp-10-4775-2010, 2010.

Stratmann, F. and Wiedensohler, A.: A new data inversion algorithm for DMPS-measurements, J. Aerosol Sci., 27, S339-S340, doi:10.1016/0021-8502(96)00242-X, 1996.

Su, H., Rose, D., Cheng, Y. F., Gunthe, S. S., Massling, A., Stock, M., Wiedensohler, A., Andreae, M. O., and Pöschl, U.: Hygroscopicity distribution concept for measurement data analysis and modeling of aerosol particle mixing state with regard to hygroscopic growth and CCN activation, Atmos. Chem. Phys., 10, 7489-7503, doi:10.5194/acp-10-7489-2010, 2010.

Tunved, P., Hansson, H. C., Kerminen, V. M., Strom, J., Dal Maso, M., Lihavainen, H., Viisanen, Y., Aalto, P. P., Komppula, M., and Kulmala, M.: High natural aerosol loading over boreal forests, Science, 312, 261-263, 2006.

van der Werf, G. R., Randerson, J. T., Giglio, L., Collatz, G. J., Mu, M., Kasibhatla, P. S., Morton, D. C., DeFries, R. S., Jin, Y., and van Leeuwen, T. T.: Global fire emissions and the contribution of deforestation, savanna, forest, agricultural, and peat fires (19972009), Atmos. Chem. Phys., 10, 11707-11735, doi:10.5194/acp10-11707-2010, 2010.

Vasileva, A. V., Moiseenko, K. B., Mayer, J. C., Jurgens, N., Panov, A., Heimann, M., and Andreae, M. O.: Assessment of the regional atmospheric impact of wildfire emissions based on $\mathrm{CO}$ observations at the ZOTTO tall tower station in central Siberia, J. Geophys. Res., 116, D07301, doi:10.1029/2010JD014571, 2011.

Veldt, http://themasites.pbl.nl/en/themasites/edgar/documentation/ content/Temporal-variation.html (last access: September 2012), 2009. 
Verma, R. L., Kondo, Y., Oshima, N., Matsui, H., Kita, K., Sahu, L. K., Kato, S., Kajii, Y., Takami, A., and Miyakawa, T.: Seasonal variations of the transport of black carbon and carbon monoxide from the Asian continent to the western Pacific in the boundary layer, J. Geophys. Res., 116, D21307, doi:10.1029/2011JD015830, 2011.

Virkkula, A., Ahlquist, N. C., Covert, D. S., Arnott, W. P., Sheridan, P. J., Quinn, P. K., and Coffman, D. J.: Modification, calibration and a field test of an instrument for measuring light absorption by particles, Aerosol Sci. Tech., 39, 68-83, 2005.

Virkkula, A., Backman, J., Aalto, P. P., Hulkkonen, M., Riuttanen, L., Nieminen, T., dal Maso, M., Sogacheva, L., de Leeuw, G., and Kulmala, M.: Seasonal cycle, size dependencies, and source analyses of aerosol optical properties at the SMEAR II measurement station in Hyytiälä, Finland, Atmos. Chem. Phys., 11, 4445-4468, doi:10.5194/acp-11-4445-2011, 2011.

Vrekoussis, M., Liakakou, E., Kocak, M., Kubilay, N., Oikonomou, K., Sciare, J., and Mihalopoulos, N.: Seasonal variability of optical properties of aerosols in the Eastern Mediterranean, Atmos. Environ., 39, 7083-7094, 2005.

Waggoner, A. P., Weiss, A. P., Ahlquist, N. C., Covert, D. S., and Charlson, R. J.: Optical characteristics of atmospheric aerosols, Atmos. Environ., 15, 1891-1909, 1981.

Walter, D., Heue, K. P., Rauthe-Schoch, A., Brenninkmeijer, C. A. M., Lamsal, L. N., Krotkov, N. A., and Platt, U.: Flux calculation using CARIBIC DOAS aircraft measurements: SO2 emission of Norilsk, J. Geophys. Res., 117, D11305, doi:10.1029/2011jd017335, 2012.

Wang, Y. X., Wang, X., Kondo, Y., Kajino, M., Munger, J. W., and Hao, J. M.: Black carbon and its correlation with trace gases at a rural site in Beijing: Top-down constraints from ambient measurements on bottom-up emissions, J. Geophys. Res., 116, D24304, doi:10.1029/2011JD016575, 2011.

Warneke, C., Bahreini, R., Brioude, J., Brock, C. A., de Gouw, J. A., Fahey, D. W., Froyd, K. D., Holloway, J. S., Middlebrook, A., Miller, L., Montzka, S., Murphy, D. M., Peischl, J., Ryerson, T. B., Schwarz, J. P., Spackman, J. R., and Veres, P.: Biomass burning in Siberia and Kazakhstan as an important source for haze over the Alaskan Arctic in April 2008, Geophys. Res. Lett., 36, L02813, doi:10.1029/2008GL036194, 2009.

Warton, D. I. and Weber, N. C.: Common slope tests for bivariate errors-in-variables models, Biometrical J., 44, 161-174, 2002.

Weingartner, E., Saathoff, H., Schnaiter, M., Streit, N., Bitnar, B., and Baltensperger, U.: Absorption of light by soot particles: determination of the absorption coefficient by means of aethalometers, J. Aerosol Sci., 34, 1445-1463, 2003.

Whitby, K. T.: Physical characteristics of sulfur aerosols, Atmos. Environ., 12, 135-159, 1978.

Wiedensohler, A., Cheng, Y. F., Nowak, A., Wehner, B., Achtert, P., Berghof, M., Birmili, W., Hu, M., Zhu, T., Takegawa, N., Kita, K., Kondo, Y., Lou, S. R., Hofzumahaus, A., Holland, F., Wahner, A., Gunthe, S. S., Rose, D., Su, H., and Pöschl, U.: Rapid aerosol particle growth and increase of cloud condensation nucleus activity by secondary aerosol formation and condensation; A case study for regional air pollution in northeastern China, J. Geophys. Res., 114, D00G08, doi:10.1029/2008JD010884, 2009.
Winderlich, J., Chen, H., Gerbig, C., Seifert, T., Kolle, O., Lavrič, J. V., Kaiser, C., Höfer, A., and Heimann, M.: Continuous lowmaintenance $\mathrm{CO} 2 / \mathrm{CH}_{4} / \mathrm{H} 2 \mathrm{O}$ measurements at the Zotino Tall Tower Observatory (ZOTTO) in Central Siberia, Atmos. Meas. Tech., 3, 1113-1128, doi:10.5194/amt-3-1113-2010, 2010.

Winklmayr, W., Reischl, G. P., Lindner, A. O., and Berner, A.: A new electromobility spectrometer for the measurement of aerosol size distributions in the size range from 1 to $1000 \mathrm{~nm}$, J. Aerosol Sci., 22, 289-296, 1991.

Wu, Z. J., Cheng, Y. F., Hu, M., Wehner, B., Sugimoto, N., and Wiedensohler, A.: Dust events in Beijing, China (20042006): comparison of ground-based measurements with columnar integrated observations, Atmos. Chem. Phys., 9, 6915-6932, doi:10.5194/acp-9-6915-2009, 2009.

Yttri, K. E., Aas, W., Bjerke, A., Cape, J. N., Cavalli, F., Ceburnis, D., Dye, C., Emblico, L., Facchini, M. C., Forster, C., Hanssen, J. E., Hansson, H. C., Jennings, S. G., Maenhaut, W., Putaud, J. P., and Tørseth, K.: Elemental and organic carbon in $\mathrm{PM}_{10}$ : a one year measurement campaign within the European Monitoring and Evaluation Programme EMEP, Atmos. Chem. Phys., 7, 5711-5725, doi:10.5194/acp-7-5711-2007, 2007.

Yurganov, L. N., Duchatelet, P., Dzhola, A. V., Edwards, D. P., Hase, F., Kramer, I., Mahieu, E., Mellqvist, J., Notholt, J., Novelli, P. C., Rockmann, A., Scheel, H. E., Schneider, M., Schulz, A., Strandberg, A., Sussmann, R., Tanimoto, H., Velazco, V., Drummond, J. R., and Gille, J. C.: Increased Northern Hemispheric carbon monoxide burden in the troposphere in 2002 and 2003 detected from the ground and from space, Atmos. Chem. Phys., 5, 563-573, doi:10.5194/acp-5-563-2005, 2005.

Zhang, L., Jacob, D. J., Boersma, K. F., Jaffe, D. A., Olson, J. R., Bowman, K. W., Worden, J. R., Thompson, A. M., Avery, M. A., Cohen, R. C., Dibb, J. E., Flock, F. M., Fuelberg, H. E., Huey, L. G., McMillan, W. W., Singh, H. B., and Weinheimer, A. J.: Transpacific transport of ozone pollution and the effect of recent Asian emission increases on air quality in North America: an integrated analysis using satellite, aircraft, ozonesonde, and surface observations, Atmos. Chem. Phys., 8, 6117-6136, doi:10.5194/acp-8-6117-2008, 2008.

Zhang, F., Zhou, L. X., Novelli, P. C., Worthy, D. E. J., Zellweger, C., Klausen, J., Ernst, M., Steinbacher, M., Cai, Y. X., Xu, L., Fang, S. X., and Yao, B.: Evaluation of in situ measurements of atmospheric carbon monoxide at Mount Waliguan, China, Atmos. Chem. Phys., 11, 5195-5206, doi:10.5194/acp-11-51952011, 2011a.

Zhang, X. L., Lin, Y. H., Surratt, J. D., Zotter, P., Prevot, A. S. H., and Weber, R. J.: Light-absorbing soluble organic aerosol in Los Angeles and Atlanta: A contrast in secondary organic aerosol, Geophys. Res. Lett., 38, L21810, doi:10.1029/2011GL049385, 2011b. 